\title{
The Sustainability Assessment of Plantation Agriculture - A Systematic Review of Sustainability Indicators
}

\author{
Dinish Nadaraja $^{\mathrm{a}}$, Chungui Lu ${ }^{\mathrm{a}}$, Md Mofakkarul Islam ${ }^{\mathrm{b}}$ \\ ${ }^{a}$ School of Animal, Rural and Environmental Sciences, Nottingham Trent University, \\ Brackenhurst, Sothwell NG25 0QF, Nottingham, UK \\ ${ }^{b}$ Natural Resources Institute, University of Greenwich, Medway Campus, Central Avenue, \\ Chatham Maritime ME4 4TB, UK
}

\begin{abstract}
The unsustainable growth of the plantation agricultural sector has caused numerous sustainability challenges including environmental, economic, social and governance concerns. Although a wide variety of sustainability indicators have been developed to monitor and assess the sustainability issues for agriculture in general, few, if any have been developed specifically for plantation agriculture. In response to this, we conducted a systematic review of the literature in order to identify the most commonly used or suggested indicators of sustainability in plantation agriculture and to identify the critical issues in the development of a comprehensive and unambiguous set of sustainability indicators for plantation agriculture. We used the Preferred Reporting Items for Systematic Reviews and Meta-Analysis (PRISMA) method in our systematic review. Following the screening of a large number of articles identified through database searches, 40 articles were finally selected and analysed in this study. The results of the analysis (i.e. indicators) were organized according to the sustainability indicator framework developed by the United Nations Commissions on Sustainable Development (UNCSD). A total of 47 commonly used or suggested indicators relevant for assessing the sustainability of plantation agricultural systems, along with the potential issues in their application were identified. Although it was possible to identify relevant indicators, it was difficult to conclusively identify a universal set of indicators to assess the sustainability of different plantation agricultural systems. We conclude that although
\end{abstract}


developing a suite of sustainability indicators that cover the environmental, social, economic and governance dimensions can add value to agricultural plantations, there is a need to develop sustainability indicators via a bottom up and participatory approach to select a suite of sustainability indicators for plantation agriculture that are not only relevant but can be acceptable to a wide range of stakeholder groups.

Keywords: Plantation Agriculture, Sustainability, Indicators, Systematic Review 


\section{Introduction}

Despite their widespread criticism (Fitzherbert et al. 2008; FAO 2013; Hall, Scoones \& Tsikata 2017) and colonial past (Jayeeta 2009; Kothari 2013), plantations are still among the fastest growing agricultural systems within many tropical countries, mainly due to the increasing demands for plantation commodities (e.g. palm oil, sugarcane, cocoa and rubber) worldwide (Gerber 2011). For example, from 1990 to 2005, palm oil plantations have increased from 1.8 million hectares to 4.2 million hectares and from 4.4 million hectares to 6.1 million hectares in Malaysia and Indonesia respectively (Fitzherbert et al. 2008). According to Hartemik (2005), plantation agriculture is typically defined as a large-scale, often foreign owned and specialized, high-input and high-output farming system that is mostly export oriented.

For many countries, plantation agriculture has become a vital source of national income and wealth (Hartemik 2005). For example, in Ghana, exports from cocoa accounts for approximately $60 \%$ of the country's earnings, while in Indonesia, the revenue from cocoa is approximately USD 600 million per year (Hartemink 2005). However, the rapid expansion of plantation areas has created undesirable side impacts, both environmental and social. On the environmental front, unsustainable plantation growth is often accused of causing increased emissions of greenhouse gases (GHGs), loss of biodiversity, water cycle destabilization, soil erosion, nutrient loss as well as land and water pollution (Zapfack et al. 2002; Fitzherbert et al. 2008; Wicke et al. 2011).

On the social front, plantations have sometimes involved the forceful takeover of lands and related resources thereby displacing local populations, disrupting local livelihoods, and resulting in land conflicts (Hall, Scoones \& Tsikata 2017). In Latin America, for instance, sugarcane and palm oil plantations are typically developed on native forests which these communities depend on for water, food and building materials as well as on lands that they use to grow staple crops (Mingorría 2018). This disregard for traditional land use and customary rights is one of the major sources of conflict between plantation developers and local communities (Obidzinski et al. 2012). Moreover, although plantations typically employ numerous unskilled labourers due to their large sizes, they have been associated with serious labour issues ranging from unfair firing, violence as well as inadequate and inconsistent wage payments (FAO 2013). 
Such undesirable consequences have resulted in a major overhaul of plantation operations, primarily by consumers and civil society organizations. Ostfeld et al. (2019) found that many British consumers perceived palm oil as more environmentally unfriendly compared to any other vegetable oil. Environmental non-governmental organizations (NGOs), such as Greenpeace, are also linking environmental issues with the brands of major agribusinesses, such as Nestle and Unilever, thereby compelling these businesses to ban and remove unsustainably produced agricultural products from their supply chains (Edwards \& Laurance 2012). These forces, in turn, are forcing primary producers (plantation companies) to incorporate sustainable production policies within their business operations (Edwards \& Laurance 2012). Sustainability thus emerging as crucial for market competitiveness and survival of plantation companies and agribusinesses (Sheth, Sethia, \& Srinivas 2011).

Sustainability, however, can be a term without substance unless corresponding 'indicators' are available (The World Bank 1998). A sustainability indicator can be defined as the operational representation of an attribute of a system (Waas et al. 2014). It allows specific attributes of that system to be measured in order to monitor changes in that system, relevant to the continuation of human and environmental well-being (EPA 2012). Over the decades, numerous indicators for assessing the sustainability of agricultural systems have been developed and reviewed by researchers, academics, governments and NGOs (Rasmussen et al. 2017; Xavier et al. 2018; Lynch et al. 2019). The indicators, along with their rationale and measurement methods, are packaged together as sustainability assessment 'toolkits'. Examples of these toolkits include SAFA, RISE, PG, and IDEA (Gasparatos 2010). Various certification schemes (mostly voluntary) have also emerged that employ these toolkits. Examples include Organic, Fairtrade and Rainforest Alliance certification schemes.

The existing indicators, however, suffer from notable shortcomings when it comes to the sustainability assessment of plantation agriculture. Since very few (if any) of these sustainability assessment toolkits have been developed specifically for plantation agriculture, the corresponding indicators do not adequately reflect the sustainability challenges and norms specific to plantation agriculture. Other problems also include the legitimacy and validity of the indicators, including those used by voluntary/private certification schemes. For instance, it is noted that different certification schemes often differ in their definition of sustainability and the selection and 
measurement of corresponding indicators, thereby leading to confusion, disagreements and scepticism (IISD 2009; Partzsch 2011; Latruffe et al. 2016). Thus, many existing certification schemes have been criticised especially by NGOs' as 'greenwashing' (Partzsch, Zander, \& Robinson 2019).

Our aim in this paper is to identify, through a systematic review of the literature, an appropriate suite of indicators that can be used to assess the sustainability of plantation agricultural systems. For this, we intend to critically evaluate: (i) the relevance of the indicators found within the literature in terms of assessing the sustainability of plantation agricultural systems, (ii) the number of articles using or suggesting the identified indicators and (iii) the potential issues in the application of the indicators (e.g. availability of data, ease of use, limited measurement guidelines, etc).

\section{Methodology}

\subsection{Analytical Framework}

In this research, we have used a modified version of the sustainability framework developed by the United Nations Commissions on Sustainable Development (UNCSD) as our analytical framework. The UNCSD framework has been used to assess the sustainability of agricultural systems (UN 2007). Moreover, this framework encompasses the governance (institutional) dimension of sustainability, in addition to the other three commonly accepted dimensions including (environmental, economic and social), thereby representing a broad version of sustainability (Porio 2015). As governance is central to creating, implementing and enforcing decisions within the other dimensions, the absence of this dimension can hinder the overall progress of sustainability (FAO 2013; Porio 2015). 
Table 1: The modified UNCSD framework used in this investigation to structure data analysis

\begin{tabular}{|c|c|c|}
\hline Dimensions & Themes & Indicators \\
\hline \multirow[t]{18}{*}{ Environment } & \multirow{4}{*}{ Atmosphere and Water } & Life cycle GHG emissions \\
\hline & & Water conservation measures \\
\hline & & Water contamination prevention practices \\
\hline & & Amount of water needed for irrigation \\
\hline & \multirow{8}{*}{ Land } & Manure management \\
\hline & & Amount of fertilizer used \\
\hline & & Intercropping \\
\hline & & Tillage practices \\
\hline & & Crop rotation \\
\hline & & Soil Nutrient Content \\
\hline & & Soil Physical Properties \\
\hline & & Soil Chemical Properties \\
\hline & \multirow{6}{*}{$\begin{array}{l}\text { Biodiversity and Materials and } \\
\text { Energy }\end{array}$} & Diversity and Abundance of Key Species \\
\hline & & Tree Species Diversity \\
\hline & & Diversity of crops across the landscape \\
\hline & & $\begin{array}{l}\text { Total area of natural vegetation converted for } \\
\text { agricultural production }\end{array}$ \\
\hline & & Existence of recycling programs \\
\hline & & Energy saving practices \\
\hline \multirow[t]{11}{*}{ Social } & \multirow{6}{*}{$\begin{array}{l}\text { Labour Rights and Safety and } \\
\text { Health }\end{array}$} & Child labour \\
\hline & & Forced labour \\
\hline & & Access to adequate protective equipment \\
\hline & & Access to health care insurance \\
\hline & & Access to potable water \\
\hline & & Number of worker incidences per year \\
\hline & \multirow{5}{*}{ Equity and Decent Livelihood } & Discrimination in employment \\
\hline & & $\begin{array}{l}\text { Gender wage differentials for the same quantity of } \\
\text { work }\end{array}$ \\
\hline & & Training for workers \\
\hline & & Wage categories of employees \\
\hline & & Average working hours per week \\
\hline \multirow[t]{7}{*}{ Economic } & \multirow{7}{*}{ Investment } & Overall farm revenue \\
\hline & & Net Income \\
\hline & & Profit \\
\hline & & Crop Yield \\
\hline & & Selling Price \\
\hline & & Internal rate of return \\
\hline & & Net Present Value \\
\hline
\end{tabular}




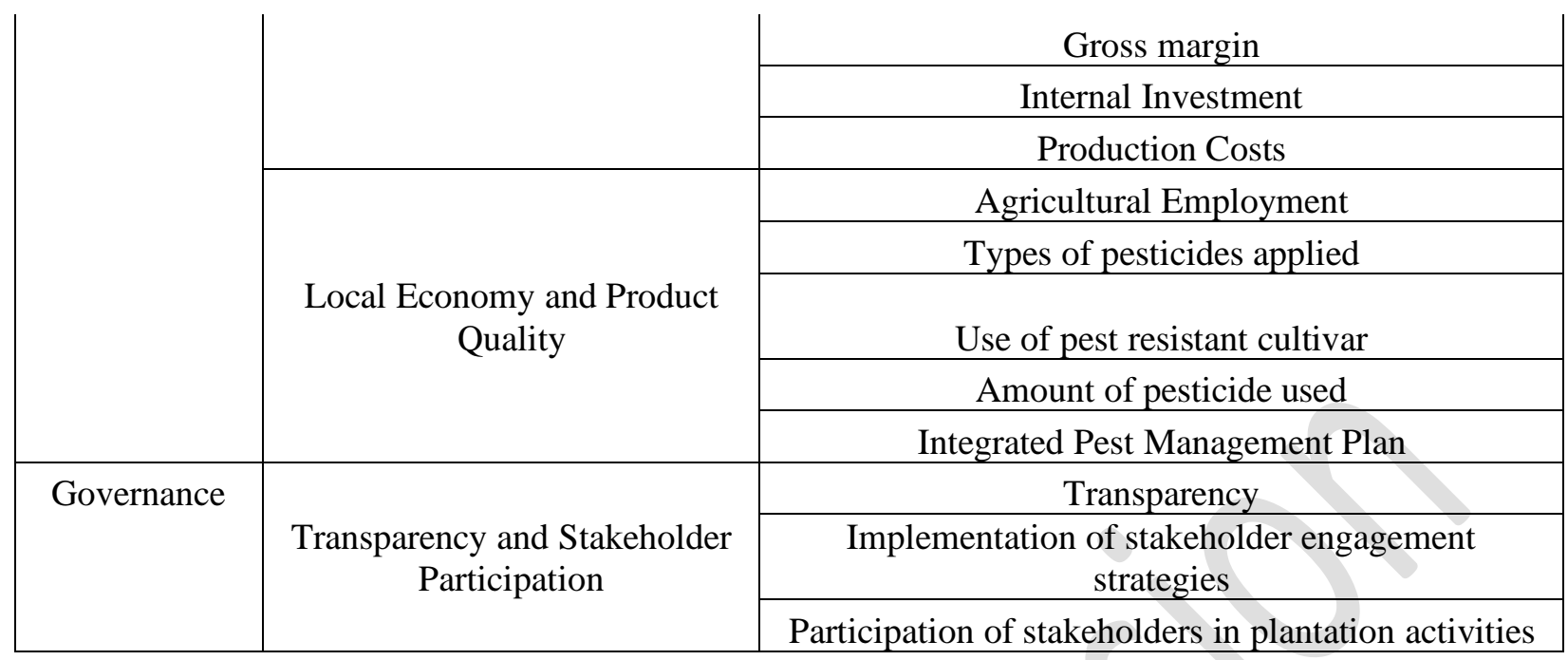

Within this modified framework, there are three hierarchical levels (See Table 1). "Dimensions" - including, Environmental, Economic, Social and Governance - are the highest and most general level in the framework (FAO 2013). "Themes" sit below the "Dimensions" level and encompass universal sustainability goals (FAO 2013; De Olde et al. 2016). For example, under the environmental dimension, some common themes include land, water and atmosphere (FAO 2013). "Indicators" sit at the lowest level in the framework and are measurable variables to evaluate sustainability performances within specific themes (Van Cauwenbergh et al. 2007; Olde et al. 2016). For example, under the land theme, some common indicators to monitor the productivity of agricultural lands include tillage practices and fertilizer use (FAO 2013).

\subsection{Data Acquisition and Analysis}

The Preferred Reporting Items for Systematic Reviews and Meta-analysis (PRISMA) flowchart was used to identify and select articles for this analysis (See Appendix B in supplementary material). PRISMA is an evidence-based checklist developed to act as a guideline for conducting systematic reviews (See Liberati et al. 2009). The PRISMA framework is widely used in order to improve the clarity, transparency and completeness of systematic review reporting (Li et al. 2020). Two scientific databases - Scopus and Web of Science - were initially used to select articles for this analysis. Successively, it was noticed that Web of Science was giving approximately the same number of hits and the same articles as Scopus. Therefore, Web of Science was not included in the final search. 
Articles were identified via abstract, title and keyword searches. The search terms were put into triplets to improve the specificity of the search results and to identify a wide range of articles specific to sustainability within plantation agriculture (See Appendix C in supplementary material). The records identified via the database search were supplemented with grey literature obtained from Google Scholar and Google searches for a more comprehensive coverage of the indicators used to assess the sustainability of plantation agricultural systems.

For this research, we primarily followed the definition of plantation agriculture as provided by Hartemink (2005) and Hall, Scoones \& Tsikata (2017). Accordingly, we associate plantations with the following five characteristics:

- Monoculture based agriculture (cultivation of one or more crop)

- Involves high amounts of capital investment (e.g. infrastructure)

- Cultivated on substantial tracts of land

- Relies on large numbers of hired, resident or non-resident labour including migrant labour - Top-down management system (centrally managed)

As such, peer-reviewed articles were assessed to identify the: type of crop, plantation size area, size of workforce, amount of capital invested, type of management system, and type of indicators (empirical or prescriptive) suggested. Articles were only included into the final assessment if they stated the type of crop, and one or more of the other criteria. As most of the grey literature identified were on sustainability assessment toolkits used by different organizations, these articles were only included into the final assessment if they provided_relevant examples of sustainability indictors for plantation agriculture. After the eligibility assessment, 40 documents were considered suitable to be included in the analysis (See Appendix A).

The peer-reviewed articles included in this research are listed in Table 2. The criteria; Capital Investment, was omitted from the table as none of the articles included in this research stated it. 
Table 2: List of the peer-reviewed articles included in this research

\begin{tabular}{|c|c|c|c|c|}
\hline References* & Crop Type & $\begin{array}{c}\text { Size of } \\
\text { Cultivation } \\
\text { Area } \\
\end{array}$ & $\begin{array}{c}\text { Size of } \\
\text { Workforce }\end{array}$ & $\begin{array}{c}\text { Management } \\
\text { type }\end{array}$ \\
\hline Bonilla et al. 2010 & Bamboo & 1 ha & Not Stated & Not Stated \\
\hline Bellamy et al. 2016 & Banana & $120-320$ ha & Not Stated & Top Down \\
\hline Coote et al. 2013 & $\begin{array}{l}\text { Pine, Oak, Sitka } \\
\text { spruce }\end{array}$ & $x>5$ ha & Not Stated & Not Stated \\
\hline Chopin et al. 2015 & Banana & $\begin{array}{c}\text { Average area is } \\
4 \text { ha }\end{array}$ & Not Stated & Not Stated \\
\hline Chopin et al. 2016 & Banana & Not Stated & Not Stated & Top Down \\
\hline Dantsis et al. 2010 & $\begin{array}{c}\text { Olives and citrus } \\
\text { trees }\end{array}$ & $\begin{array}{c}\text { Cultivation } \\
\text { area covered } \\
\text { more than } \\
25,844,000 \text { ha }\end{array}$ & Not Stated & Not Stated \\
\hline $\begin{array}{c}\text { Diaz-Balteiro et al. } \\
2016\end{array}$ & Eucalyptus & $20-400$ ha & Not Stated & Top down \\
\hline Elfkih et al. 2012 & Olive & $\begin{array}{c}\text { Average is } 100 \\
\text { ha }\end{array}$ & Not Stated & Not Stated \\
\hline Fleskens et al. 2009 & Olive & $1.2-2.1 \mathrm{ha}$ & Not Stated & Not Stated \\
\hline $\begin{array}{l}\text { Gómez-Limón \& Riesgo } \\
2009 \\
\end{array}$ & $\begin{array}{l}\text { Maize, barley, } \\
\text { wheat }\end{array}$ & $40-60$ ha & Not Stated & Not Stated \\
\hline $\begin{array}{c}\text { Gartzia-Bengoetxea et } \\
\text { al. } 2009\end{array}$ & Pine & 1 ha & Not Stated & Not Stated \\
\hline Giménez et al. 2013 & Eucalyptus & $166.6 \mathrm{ha}$ & Not Stated & Not Stated \\
\hline Gaudino et al. 2014 & $\begin{array}{l}\text { Maize, winter } \\
\text { cereal, soybeans }\end{array}$ & $36-80$ ha & Not Stated & Not Stated \\
\hline Hartemink 1998 & Sugarcane & 6030 ha & Not Stated & Not Stated \\
\hline Ingram et al. 2016 & $\begin{array}{l}\text { Pine and } \\
\text { Eucalyptus }\end{array}$ & Not Stated & 51 workers & Top down \\
\hline Jacobi et al. 2015 & Cocoa & $1-5$ ha & Not Stated & Not Stated \\
\hline Munyanduki et al. 2016 & Forest (Timber) & 92.7 ha & Not Stated & Top down \\
\hline Pineda et al. 2005 & Coffee & 41- 104 ha & Not Stated & Not Stated \\
\hline Pretty et al. 2008 & Tea & 3000 - 8000 ha & Not Stated & Top down \\
\hline
\end{tabular}




\begin{tabular}{|c|c|c|c|c|}
\hline $\begin{array}{c}\text { Prasara-A \& Gheewala } \\
2016\end{array}$ & Sugarcane & $2-32$ ha & $\begin{array}{l}10 \text { to } 30 \\
\text { workers }\end{array}$ & Not Stated \\
\hline Rodrigues et al. 2018 & Coconut & $60-6000$ ha & Not stated & Top down \\
\hline Smith et al. 2008 & Sitka and Ash & 4 ha & Not Stated & Not Stated \\
\hline Sydorovych et al. 2009 & Walnut & $1.2-3.8 \mathrm{ha}$ & Not stated & Not stated \\
\hline Singh \& Benbi 2016 & Rice & $2-10$ ha & Not Stated & Not Stated \\
\hline Sun et al. 2017 & Ginkgo & 30,000 ha & Not Stated & Not Stated \\
\hline Safitri et al. 2018 & Palm oil & 22,457 ha & Not Stated & Not Stated \\
\hline Schweier et al. 2018 & Pine & 14,000 ha & Not Stated & Not Stated \\
\hline $\begin{array}{c}\text { Tellarini \& Caporali } \\
2000 \\
\end{array}$ & $\begin{array}{c}\text { Olive, wheat, } \\
\text { barley, oat }\end{array}$ & $2-4$ ha & Not Stated & Not Stated \\
\hline Thivierge et al. 2014 & Wheat, oat, barley & $41-348.2$ ha & Not Stated & Not Stated \\
\hline Testa et al. 2015 & Lemon & 22 ha & Not Stated & Not Stated \\
\hline Utomo et al. 2016 & Cocoa & Not Stated & Not Stated & Top down \\
\hline Van Eijck et al. 2014 & Jatropha & 80,000 ha & $\begin{array}{c}35,000 \\
\text { workers }\end{array}$ & Top down \\
\hline Vanhove et al. 2016 & Cocoa & 61 ha & Not Stated & Not Stated \\
\hline Xu et al. 2008 & Bamboo & $1-1.5$ ha & Not Stated & Not Stated \\
\hline Yi et al. 2014 & Rubber & 15,100 ha & Not Stated & Not Stated \\
\hline Zhang et al. 2017 & Citrus & 200,000 ha & Not Stated & Not Stated \\
\hline
\end{tabular}

*See Appendix A for bibliographic details of these listed articles

The articles were analyzed using the $\mathrm{NVIVO}^{\mathrm{TM}} 11$ software following a thematic analysis approach (See Braun \& Clarke 2006). The articles were coded into specific themes, namely the definition of sustainability suggested by the authors, sustainability indicators suggested, methods to measure the suggested sustainability indicators, potential issues in the application of the identified sustainability indicators and whether the suggested indicators were tested or prescribed. The themes were categorized using the UNCSD framework (See Table 1). 


\section{Results and Discussion}

A total of 307 indicators were identified covering all the four dimensions of sustainability within the UNCSD framework (See Appendix D in supplementary material).

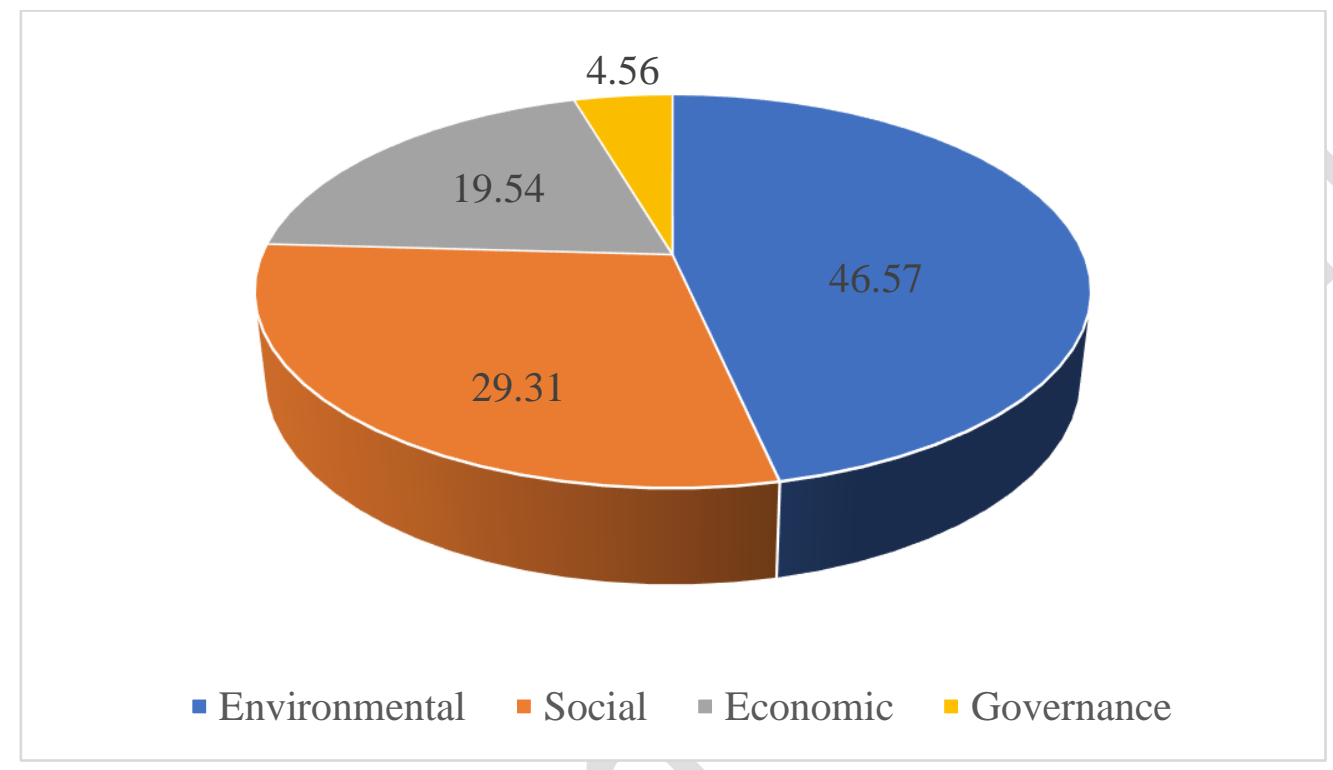

Figure 1: Proportion of indicators by sustainability dimension

As indicated in Figure 1, the highest proportion (46.57\%) of these indicators related to the 'Environmental' dimension of sustainability, followed by the 'Social' dimension (29.31\%) and the 'Economic' dimension (19.54\%). The lowest proportion (4.56\%) belonged to the 'Governance' dimension. Full details of all the indicators are attached as supplementary material with this article (See Appendix D). During the analysis, it was indicated that despite being termed differently, many of the identified indicators could be grouped under a single indicator. For example, the indicators; 'GHG Reduction Target' and 'GHG Mitigation Practices' all relate to GHG emissions. Therefore, these indicators can be grouped under the indicator 'Life Cycle GHG Emissions'. As such, during the analysis process, similar indicators were grouped under a single indicator within a particular theme for simplicity. During this process, it was indicated that the indicators that could be grouped together were also more commonly used/suggested compared to the indicators that could not be suggested together.

In the subsequent sections, we discuss only the most commonly suggested indicators. For this, we used the number of articles within our sample as an indication of whether an indicator was 
commonly used/suggested or not. The indicators must have been used/suggested by at least 2 articles to be included.

\subsection{Environmental Dimension}

A total of 143 indicators were identified under the 'Environmental' dimension (See Appendix D). A portion of these indicators could be grouped together into 18 indicators (See Table 3, Table 4 and Table 5). These indicators were further categorized into five sustainability themes. These five themes include: atmosphere, water, land, biodiversity and materials and energy.

\subsubsection{Atmosphere and Water}

Four indicators; 'Life cycle GHG emissions', 'Water conservation measures', 'Water contamination prevention practices' and 'Amount of water needed for irrigation' were suggested under the atmosphere and water theme within the environmental dimension (See Table 3).

Table 3: Indicators suggested under the atmosphere and water theme within the environmental dimension

\begin{tabular}{|c|c|c|}
\hline \multicolumn{3}{|c|}{ Theme: Atmosphere and Water } \\
\hline Indicator & Measurement & References \\
\hline Life cycle GHG emissions & $\begin{array}{l}\text { Satellite data calibrated with field } \\
\text { measurements of GHG emissions using } \\
\text { IPCC methodology }\end{array}$ & $\begin{array}{l}\text { Gaudino et al. 2014; Van Eijck } \\
\text { et al. } 2014\end{array}$ \\
\hline Water conservation measures & No specific methods provided & COSA 2013; FAO 2013 \\
\hline $\begin{array}{l}\text { Water contamination prevention } \\
\text { practices }\end{array}$ & No specific methods provided & COSA 2013; FAO 2013 \\
\hline $\begin{array}{l}\text { Amount of water needed for } \\
\text { irrigation }\end{array}$ & $\begin{array}{l}\text { (1) Blaney-Griddle method based on the } \\
\text { irrigation technology adopted by the farm. } \\
\text { (2) Aggregation of cropping system needs } \\
\text { for water based on quantity of rainfall and } \\
\text { average crop needs per month }\end{array}$ & $\begin{array}{l}\text { Pretty et al. 2008; Gómez- } \\
\text { Limón, \& Riesgo 2009; } \\
\text { Dantsis et al. 2010; Gaudino et } \\
\text { al. 2014; Chopin et al. } 2015\end{array}$ \\
\hline
\end{tabular}

The indicator 'Life cycle GHG emissions' refer to the emissions of GHGs such as $\mathrm{CO}_{2}, \mathrm{CH}_{4}$ and $\mathrm{N}_{2} \mathrm{O}$ at each stage of the supply chain (Van Eijck et al. 2014). Plantation agriculture contributes to GHG emissions through various practices including land clearance, deforestation and high use of 
fossil fuels (FAO 2013). It is now widely evident that these emissions contribute to climate change and global warming, which in turn could affect yields and productivity (Johnson et al. 2007). This indicator therefore is highly relevant to the sustainability of plantation systems.

However, only two studies were found to have tested this indictor (See Table 3). In the sampled articles, life cycle GHG emissions from plantation systems was measured as carbon dioxide equivalents $\left(\mathrm{CO}_{2} \mathrm{eq}\right)$ through satellite data and calibrated with field measurements using the IPCC methodology (Gaudino et al. 2014; Van Eijck et al. 2014). There may be several issues with this method. Access to satellite data may not be available, particularly in many developing countries due to high costs and inadequate international coordination (DeFries et al. 2007). Furthermore, as this indicator considers $\mathrm{N}_{2} \mathrm{O}$ emissions from diesel consumption only, it does not provide an accurate estimation of GHG emissions (Gaudino et al. 2014). Other factors such as changes in land use (e.g. deforestation) can also contribute to GHG emissions (DeFries et al. 2007).

The indicators 'Water conservation measures' and 'Water contamination prevention practices' refer to the practices necessary to reduce freshwater use and water pollution respectively (FAO 2013). One of the main factors limiting crop production within agricultural systems is the availability of freshwater (FAO 2013). As the global population is expected to increase to 9 billion by 2050 (Béné 2015), more freshwater will be required to increase agricultural productivity to keep up with global demand and consumption. Therefore, both these indicators are highly relevant to the sustainability of plantation systems.

However, the use of both these indicators are questionable as the two studies that have mentioned both these indicators have only prescribed them (See Table 3). As such, both these indicators have not been tested. In the sampled articles, no specific methods were suggested to measure both water conservation measures and water contamination prevention practices. There may be several issues with this. Although the sampled articles (See COSA 2013; FAO 2013) provided guidelines regarding 'best' and 'worst' practices, it was ultimately up to the assessor to determine the types of practices as well as the minimum number of practices required to be sustainable (FAO 2013). As such, different users can determine the type and number of practices to apply without a reliable benchmark to ensure that these practices actually meet the necessary sustainability requirements (Williams \& Walcott 1998). 
The indicator 'Amount of water needed for irrigation' refer to the quantity of water required to irrigate the crops within the plantation systems (Pretty et al. 2008; Dantsis et al. 2010). Unsustainable use of water for irrigation purposes can cause environmental issues such as salinization, desertification as well as leaching and runoff of nutrients and pesticides to ground and surface water (Pretty et al. 2008; Singh 2009). Furthermore, as different crops have different water requirements, the amount of water used for irrigation may affect both crop growth and yield (Kahlown \& Ashraf 2005). This indicator therefore is highly relevant to the sustainability of plantation systems. A total of five studies were found to have tested this indictor (See Table 3).

In the sampled articles, amount of water needed for irrigation was measured either using the Blaney-Griddle method based on the irrigation technology adopted by the farm or by aggregation of cropping system needs for water based on quantity of rainfall and average crop needs per month (See Table 3). There may be several issues with these methods. Some of these methods (e.g. Blaney-Griddle) are typically utilized in arid and semi-arid environments (Zhao et al. 2013). As such, this method might not be suitable to measure the water requirements of most plantation crops as many plantation systems are typically establish within tropical regions. Other methods (e.g. aggregation of cropping system needs) do not consider the type of irrigation system used by farms (Chopin et al. 2015). Type of irrigation system can significantly influence the water use requirements of a plantation as irrigations systems such as drip irrigation have been proven to not only reduce water use but increase crop yields as well (Al-Omran et al. 2005).

\subsubsection{Land}

The land theme had the highest number of indicators within the environmental dimension with a total of 8 indicators (See Table 4). These indicators include 'Manure management', 'Amount of fertilizer used', 'Intercropping', 'Tillage practices', 'Crop rotation', 'Soil Nutrient Content', 'Soil Physical Properties' and 'Soil Chemical Properties'. 
Table 4: Indicators suggested under the land theme within the environmental dimension

\begin{tabular}{|c|c|c|}
\hline \multicolumn{3}{|c|}{ Theme: Land } \\
\hline Indicator & Measurement & References \\
\hline Manure management & $\begin{array}{l}\text { Management of manure is based on } \\
\text { the crop and land area over which the } \\
\text { manure is applied. }\end{array}$ & $\begin{array}{l}\text { Dantsis et al. 2010; Thivierge } \text { et } \\
\text { al. } 2014\end{array}$ \\
\hline Amount of fertilizer used & $\begin{array}{l}\text { Determined as the average amount of } \\
\mathrm{N} \text { and } \mathrm{P} \text { used in each farm. Measured } \\
\text { in } \mathrm{kg} / \mathrm{ha}\end{array}$ & $\begin{array}{l}\text { Sydorovych et al. 2009; Dantsis et } \\
\text { al. 2010; Elfkih et al. } 2012\end{array}$ \\
\hline Intercropping & $\begin{array}{l}\text { Randomized block design with two } \\
\text { different crop species grown together }\end{array}$ & $\begin{array}{l}\text { Chopin et al. 2016; Zhang et al. } \\
2017\end{array}$ \\
\hline Tillage practices & $\begin{array}{l}\text { (1) Calculated as the percentage of the } \\
\text { utilized agricultural area cultivated } \\
\text { with conventional practices. (2) } \\
\text { Average number of tillage operations } \\
\text { over the years }\end{array}$ & $\begin{array}{l}\text { Sydorovych et al. 2009; Gaudino } \\
\text { et al. 2014; Thivierge et al. } 2014\end{array}$ \\
\hline Crop rotation & Measurements not mentioned & $\begin{array}{l}\text { Dantsis et al. 2010; Chopin et al. } \\
2016\end{array}$ \\
\hline Soil Nutrient Content & Soil tested by lab analysis & $\begin{array}{l}\text { Hartemink 1998; Pretty et al. } \\
\text { 2008; Sydorovych et al. 2009; } \\
\text { Gómez-Limón \& Riesgo 2009; } \\
\text { Thivierge et al. 2014; Jacobi et al. } \\
\text { 2015; Singh \& Benbi 2016; Utomo } \\
\text { et al. 2016; Zhang et al. 2017; } \\
\text { Rodrigues et al. } 2018\end{array}$ \\
\hline Soil Physical Properties & Soil tested by lab analysis & $\begin{array}{l}\text { Hartemink 1998; Pretty et al. } \\
\text { 2008; Jacobi et al. 2015; Zhang et } \\
\text { al. 2017; Rodrigues et al. 2018; } \\
\text { Schweier } \text { et al. } 2018\end{array}$ \\
\hline Soil Chemical Properties & Soil tested by lab analysis. & $\begin{array}{l}\text { Hartemink 1998; Sydorovych et al. } \\
\text { 2009; Singh \& Benbi 2016; Zhang } \\
\text { et al. 2017; Rodrigues et al. } 2018\end{array}$ \\
\hline
\end{tabular}

The indicator 'Manure management' refers to the application and management of organic manure as part of the plantation's agro-ecological management practices (Dantsis et al. 2010). Plantation activities such as excessive use of chemical fertilizers have been successful in increasing food production (crop output) but, have caused extensive environmental damage particularly to soil health and quality (Byron Houser \& Pitt 2008). Excessive use of chemical fertilizers can lead to on-site soil degradation as well as nutrient pollution (Chandran et al. 2019). As such, this indicator is highly relevant to reduce dependency on chemical fertilizers (Ning et al. 2017).

However, only two studies were found to have tested this indicator (See Table 4). In the sampled articles, manure management was measured based on the crop and land area over which organic 
manure is applied (Dantsis et al. 2010; Thivierge et al. 2014). Farms that apply manure over a large area and on growing crops are considered to have good manure management (Dantsis et al. 2010). One of the potential issues in the application of this indicator is that, as this indicator is not widely prevalent it may lack legitimacy among other stakeholder groups such as agribusinesses whom may refuse to adopt this indicator (Chandran et al. 2019). Although organic fertilizers (manure) have become an interesting issue in sustainable agriculture, it is evident that mostly the scientific community (e.g. academicians) whom are concerned with its use and application due to the increasing number of scientific papers regarding the subject (Chandran et al. 2019).

The indicator 'Amount of fertilizer used' refers to the amount fertilizers particularly chemical/inorganic fertilizers used as part of the plantation's land management practices (Sydorovych et al. 2009). Chemical fertilizers are extensively used for plantation agricultural crops as not only are they inexpensive, but they also provide immediate availability of nutrients (Chandran et al. 2019). However, excessive use of chemical fertilizers can contribute to various environmental issues including greenhouse gas emissions, eutrophication and soil degradation (Byron Houser \& Pitt 2008). Therefore, this indicator is highly relevant to prevent the excessive use of inorganic fertilizers.

A total of three studies were found to have tested this indicator (See Table 4). In the sampled articles, amount of fertilizer used was measured in kilograms per hectare based on the amount nitrogen (N) and phosphorus (P) used in each farm (Sydorovych et al. 2009; Dantsis et al. 2010; Elfkih et al. 2012). One of the potential issues in the application of this indicator is that stakeholder groups such as agribusinesses may not necessarily heed the application guidelines regarding fertilizer application quantity (Patra et al. 2016). This is unsurprising as with the rise in the global population, more fertilizers will likely be utilized to obtain more agricultural products to meet the growing demand for food consumption (Savci 2012). As such, agribusiness may have to use more than the recommended amount of fertilizers for crop production to keep up with supply demands (Patra et al. 2016).

The indicator 'Intercropping' refers to the practice of growing two or more crops together in the same field (Zhang et al. 2017). Intercropping can not only increase crop yields but also provide other ecosystem services including reducing the need for chemical inputs such as inorganic fertilizers and pesticides as well as lessening greenhouse gas emissions linked with industrial 
nitrogen fixation (Martin-Guay et al. 2018). Therefore, this indicator is highly relevant to the sustainability of the plantation agricultural system.

However, only two studies were found to have tested this indicator (See Table 4). In the sampled articles, intercropping was measured using a randomized block design with two different crop species grown together (Chopin et al. 2016; Zhang et al. 2017). One of the potential issues in the application of this indicator is the lack of guidelines regarding growing specific crop species together. Thierfelder et al. (2012) indicated that growing incompatible species together can result in reduced crop yields, increased susceptibility to pests as well as complete failure of the overall cropping system. Furthermore, farmers may also be hesitant to grow crops of no immediate economic benefit which makes the practice of intercropping highly challenging (Thierfelder et al. 2012).

The indicator 'Tillage practices' refers to the type of tillage practices carried out by the plantation as part of its land management practices (Sydorovych et al. 2009; Gaudino et al. 2014). Tillage has multiple roles in crop production including seed placement, seedbed preparation as well as pest and water management (Lobb et al. 2007). As such, the type of tillage practices carried out can not only affect crop production but also cause environmental impacts such as soil erosion, land degradation and water pollution (Lobb et al. 2007; Gaudino et al. 2014). Therefore, tillage will always be essential to crop production within plantation agricultural systems.

However, only three studies were found to have tested this indictor (See Table 4). In the sampled articles, tillage practices were measured either by calculating the percentage of the utilized agricultural area cultivated with conventional tillage practices or by estimating the average number of tillage operations over a period (Sydorovych et al. 2009; Gaudino et al. 2014; Thivierge et al. 2014). One of the potential issues in the application of this indicator is that it only considers either the size of the cultivation area or the number of tillage practices carried out (Sydorovych et al. 2009; Gaudino et al. 2014). As such, the type of tillage practices carried out is not considered. Different tillage practices (e.g. no tillage, conventional tillage and conservation tillage) can have different environmental impacts (Lobb et al. 2007). Therefore, data on the type of tillage practices carried out should also be considered to accurately reflect trends in environmental impacts which in turn can affect crop productivity and yield (Lobb \& Kachanoski 1999; Lobb et al. 2007). 
The indicator 'Crop rotation' refers to the practice of growing a series of similar or different crop types in the same area over different seasons (Chopin et al. 2016). Like intercropping, crop rotation can not only increase yield quantity but also help with pest and disease management by breaking the life cycle of crop-specific pathogens (Kirkegaard et al. 2008). Furthermore, crop rotation can also provide other benefits including improving soil fertility, reducing crop failure risks as well as providing additional income to farmers (Kirkegaard et al. 2008; Thierfelder et al. 2012).

However, only two studies were found to have tested this indicator (See Table 4). In the sampled articles, no specific methods to measure this indicator were stated (Dantsis et al. 2010; Chopin et al. 2016). Due to the vagueness of the measurement methods, a potential issue in the application of this indicator is the lack of knowledge by agribusiness on how to grow and manage different crop types under different growing seasons (Thierfelder et al. 2012). This in turn can cause agribusinesses to avoid carrying out crop rotation practices within their plantation management system (Chopin et al. 2016).

The indicator 'Soil Nutrient Content' refers to the nutrients within the soil that are essential for plant growth (Bouajila \& Gallali 2010). Of the many types of nutrients within the soil, the macronutrients (nitrogen, phosphorus and potassium) are highly essential for plant growth as they can greatly influence crop yields (Biswas \& Naher 2019). In regard to soil nutrient content, soil organic matter plays an important role as it is the storehouse for a wide range of plant nutrients especially nitrogen and phosphorus (Bouajila \& Gallali 2010; Biswas et al. 2014). Unfortunately, these soil nutrients and soil organic matter are often the most limiting factors in crops production and therefore must be managed using chemical fertilizers or organic manure (e.g. cow-dung, poultry manure) on a crop-by-crop basis (Rossel et al. 2011).

A total of ten studies were found to have tested this indicator (See Table 4). In the sampled articles, soil nutrient content was measured by lab analysis, however, the type of lab analysis used was not stated. The soils were most commonly tested for nitrogen, potassium, phosphorus and organic matter levels (Hartemink 1998; Pretty et al. 2008; Sydorovych et al. 2009). A potential issue in the application of this indicator is that it requires extensive lab analysis which can be costly and time consuming (Dunn et al. 2002).

The indicator 'Soil Physical Properties' refers to physical properties of the soil including soil structure, texture, density, porosity, colour, density, consistency, air and temperature (Osman 
2013). Of these properties, soil structure and soil texture are considered to be more important (Osman 2013). Soil structure refers to the arrangement of soil particles (silt, sand and clay) into different geometric patterns within the soil (Lipiec \& Hatano 2003). Soil texture refers to the relative proportions of these particles within the soil (Osman 2013). Together, both these soil properties regulate density, compactness, porosity, retention and movement of air and water in the soil (Jat et al. 2018).

A total of six studies were found to have tested this indicator (See Table 4). In the sampled articles, soil physical property was also measured by lab analysis, however, the type of lab analysis used for soil testing was not stated. The soils were most commonly tested for clay, sand and silt levels (Zhang et al. 2017; Rodrigues et al. 2018; Schweier et al. 2018). A potential issue in the application of this indicator is that it requires lab analysis or the use of special equipment's (e.g. penetrometer) which can be costly (Dunn et al. 2002). Although simple field tests (e.g. Spade Test) can be carried to assess the physical properties of the soil, knowledge on different soil profiles is necessary to accurately carry out soil assessments (Ingram et al. 2010).

The indicator 'Soil Chemical Properties' refers to chemical properties of the soil including $\mathrm{pH}$, cation exchange capacity (CEC), exchangeable cations as well as heavy metal concentrations. Of these properties, soil $\mathrm{pH}$ and $\mathrm{CEC}$ are considered more important. Soil $\mathrm{pH}$ measures the alkalinity or acidity of the soil which in turn can influence both plant growth as well as other soil characteristics such as soil nutrient solubility and microbial activity (Sydorovych et al. 2009; Gentili et al. 2018). Soil CEC refers to the ability of the soil to adsorb exchangeable cations that are available to the plant (Lipson \& Stotzky 1983). This in turn helps in determining the frequency and amount of cations required during fertigation (Lipson \& Stotzky 1983).

A total of five studies were found to have tested this indicator (See Table 4). In the sampled articles, soil chemical property was measured by lab analysis, however, the type of lab analysis used was not stated (Singh \& Benbi 2016; Zhang et al. 2017; Rodrigues et al. 2018). A potential issue in the application of this indicator is that the lab analysis can have a high error rate thereby resulting in inconsistent and inaccurate measurements (Sumner 1994). Furthermore, measurements via lab analysis can be costly and time consuming (Dunn et al. 2002). 


\subsubsection{Biodiversity and Materials and Energy}

Six indicators; 'Diversity and Abundance of Key Species', 'Tree Species Diversity', 'Diversity of crops across the landscape', 'Total area of natural vegetation converted for production', 'Existence of recycling programs' and 'Energy saving practices' were suggested under the biodiversity and materials and energy theme within the environmental dimension (See Table 5).

Table 5: Indicators suggested under the biodiversity and materials and energy theme within the environmental dimension

\begin{tabular}{|l|l|l|}
\hline \multicolumn{1}{|c|}{ Indicator } & \multicolumn{1}{c|}{ Measurement } & \multicolumn{1}{c|}{ References } \\
\hline $\begin{array}{l}\text { Diversity and Abundance of } \\
\text { Key Species }\end{array}$ & $\begin{array}{l}\text { Insects: Pitfall traps and Yellow bowl traps. } \\
\text { Animals: Appropriate sampling method } \\
\text { depending on the species }\end{array}$ & $\begin{array}{l}\text { Pineda } \text { et al. 2005; Jacobi } \text { et al. } \\
\text { 2015; Bellamy } \text { et al. } 2016\end{array}$ \\
\hline Tree Species Diversity & $\begin{array}{l}\text { Categorizing all tree species with a diameter of } \\
\text { more than 5cm at breast height. Assistance of } \\
\text { forestry staff is recommended. }\end{array}$ & COSA 2013; Jacobi et al. 2015 \\
\hline $\begin{array}{l}\text { Diversity of crops across the } \\
\text { landscape }\end{array}$ & $\begin{array}{l}\text { Survey farmers about the number of crop } \\
\text { varieties on the site }\end{array}$ & $\begin{array}{l}\text { Elfkih } \text { et al. 2012; Jacobi } \text { et al. } \\
\text { 2015; Chopin } \text { et al. 2016 }\end{array}$ \\
\hline $\begin{array}{l}\text { Total area of natural } \\
\text { vegetation converted for } \\
\text { production }\end{array}$ & $\begin{array}{l}\text { Quantify and determine whether there has been } \\
\text { any conversion from ecologically valuable to less } \\
\text { valuable habitats by the enterprise. }\end{array}$ & COSA 2013; FAO 2013 \\
\hline $\begin{array}{l}\text { Existence of recycling } \\
\text { programs }\end{array}$ & No specific methods mentioned & COSA 2013; FAO 2015 \\
\hline Energy saving practices & No specific methods provided & COSA 2013; FAO 2013 \\
\hline
\end{tabular}

The indicator 'Diversity and Abundance of Key Species' refers to the abundance and state of diversity of key species including vulnerable and threatened wild species (animals and insects only) due to the setup and activities of the plantation agricultural system (Pineda et al. 2005; Jacobi et al. 2015). Plantation agricultural activities are altering natural ecosystems at unprecedented intensities and scales (FAO 2013). Most of the land conversion activities for plantation expansion primarily occurs within forested areas (FAO 2013). For example, in Southeast Asia, palm oil plantations have replaced large areas of tropical rain forests to meet the growing demand for palm oil (Fitzherbert et al. 2008; Danielsen et al. 2009). Unfortunately, these plantations only support a limited number of animal and insect species compared to natural forests (Fitzherbert et al. 2008; Danielsen et al. 2009). As such, the indicator 'Diversity and Abundance of Key Species' is 
essential to ensure that plantation expansion does not further threaten endangered or vulnerable animal and insect species which in turn can cause further biodiversity loss.

However, only three studies were found to have tested this indicator (See Table 5). In the sampled articles, diversity and abundance of key species was measured either using pitfall and yellow bowl traps for insects or appropriate sampling methods depending on the type of animal species being assessed (Pineda et al. 2005; Jacobi et al. 2015; Bellamy et al. 2016). A potential issue in the application of this indicator is that this indicator heavily relied on expert consultation to correctly identify and classify different species (Pineda et al. 2005; Jacobi et al. 2015). This can be problematic particularly within developing nations due to the lack of data regarding key species within that agricultural system (Ban et al. 2009).

The indicator 'Tree Species Diversity' refers to the state of diversity of key wild or native tree species within the plantation agricultural system (Jacobi et al. 2015). The presence of wild or native tree species within the plantation agricultural lanscape helps support a diverse variety of animal and insect species (Hartley 2002). Furthermore, the presence of wild and native tree species also helps increase decomposition rates which in turn allows for faster nutrient release into the soil thereby aiding soil nutrient recycling (Byard et al. 1996). Besides this, some native tree species with rapid canopy closure can also limit weed growth which can decrease the cost of weeding over time (Byard et al. 1996). Therefore, this indicator is highly relevant to the sustainability of the plantation system.

However, only two studies were found to have tested this indicator (See Table 5). In the sampled articles, tree species diversity was measured by categorizing all tree species within the agricultural landscape with a diameter of more than $5 \mathrm{~cm}$ at breast height (COSA 2013; Jacobi et al. 2015). Like the indicator 'Diversity and Abundance of Key Species', a potential issue in the application of this indicator is that this indicator also heavily relied on expert consultation to correctly identify and classify different species (Jacobi et al. 2015). This can be problematic particularly within developing nations due to lack of expertise and data regarding the relationship between ecosystem functioning and diversity (Ban et al. 2009; Li et al. 2014).

The indicator 'Diversity of crops across the landscape' refers to the number of different crop species under production within the plantation agricultural system (Elfkih et al. 2012). A mixedspecies plantation has been indicated to be more productive compared to a single species 
(monoculture) plantation (Petit \& Montagnini 2004). Furthermore, a mixed-species plantation is able to provide farmers with more flexibility by producing a variety of products to supply an uncertain market (Petit \& Montagnini 2004). Besides this, mixed-species plantations can also reduce the incidences of diseases or insect attacks (Nichols et al. 2006).

However, only three studies were found to have tested this indicator (See Table 5). In the sampled articles, diversity of crops across the landscape was measured by surveying farmers regarding the number of crop species on site (Elfkih et al. 2012; Jacobi et al. 2015; Chopin et al. 2016). A potential issue in the application of this indicator is that the lack of interest from investors and plantation managers can be an obstacle to the adoption of a mixed-species plantation system (Forrester et al. 2006). A possible reason for this is the lack of education and enough evidence regarding the benefits of a mixed-species plantation system over a monoculture plantation system (Forrester et al. 2006).

The indicator 'Total area of natural vegetation converted for production' refers to the size of the natural or near-natural habitats (e.g. primary forests, wetlands or protected waterways) that have been replaced by ecologically less valuable forms of land use due to the plantation's operations (FAO 2013). Humans interact with natural systems for agricultural purposes by altering land for crop production (FAO 2013). According to the Food and Agriculture Organization (2011), arable land for crop production is projected to increase by $5 \%$ resulting in an expansion of 70 million ha. Almost all these land use changes are taking place in natural habitats such as tropical forests (Wicke et al. 2011). Therefore, this indicator is essential to ensure that plantation expansion does not result in further loss of natural habitats (Fitzherbert et al. 2008).

However, the two studies that have mentioned this indicator have only prescribed it (See Table 5). As such, this indicator has not been tested. In the sampled articles, total area of natural vegetation converted for agricultural production was measured by quantifying the area affected by the plantation's operations and then determining whether any conversion from ecologically valuable to less valuable habitats have occurred (COSA 2013; FAO 2013). A potential issue in the application of this indicator is that the ecological value of a habitat can be difficult to ascertain as it can depend on the values of the local stakeholders (FAO 2013). Therefore, stakeholder opinion must be considered to determine if a particular area has undergone any ecological 'upgrading' or 'downgrading' (FAO 2013). 
The indicator 'Existence of recycling programs' refers to whether the enterprise carries out recycling practices and activities to reduce waste generation and dependence on virgin (nonrenewable) materials (FAO 2013). Food supply studies worldwide have indicated that in the near future, essential increases in global food production will be required in order to feed the growing global population (Nonhebel 2005). This can only be achieved by either cultivating more crops on larger tracts of land or by cultivating high yielding crop varieties on existing arable lands (Nonhebel 2005). Both these options will require increased material and energy inputs into the agricultural system which in turn, can result in the generation of large amounts of wastes and underused by-products (Padam et al. 2014). Therefore, the recycling of waste particularly agricultural waste is essential as it can not only help overcome issues of waste generation but resource preservation as well (Okafor 1991)

However, the two studies that have mentioned this indicator have only prescribed it (See Table 5). As such, this indicator has not been tested. In the sampled articles, no specific methods to measure this indicator were stated (COSA 2013; FAO 2015). A potential issue in the application of this indicator is that some materials cannot be recycled at economically feasible cost (FAO 2013). Furthermore, due to the vagueness of the measurement methods, it can be difficult to list, classify and quantify materials that can be recycled safely, efficiently and at reduced cost (FAO 2013).

The indicator 'Energy saving practices' refers to practices carried out by the enterprise to reduce the energy needs and consumption of the plantation over time (FAO 2013). Plantation activities such as irrigation, fertilizer application, transportation as well as machinery use contribute towards higher energy consumption (Prueksakorn et al. 2010). As the size of plantation systems are expected to increase due to the worldwide demand for plantation commodities, the energy demand and consumption of these plantations will likely increase as well to due to the increase in plantation operational activities (Prueksakorn et al. 2010; Padam et al. 2014; Ludin et al. 2014). Therefore, this indicator is essential to ensure that practices and activities that can effectively reduce the energy consumption and needs of the plantation are implemented by the enterprise (FAO 2013).

However, the two studies that have mentioned this indicator have only prescribed it (See Table 5). As such, this indicator has not been tested. In the sampled articles, no specific methods to measure this indicator were stated (COSA 2013; FAO 2013). Like the indicator 'Existence of recycling programs', a potential issue in the application of this indicator is that compiling a list of suitable 
and effective energy-saving practices for the enterprise can be challenging (FAO 2013). As such, consultation with stakeholders particularly energy consultants are required to ensure that the list of practices can be used as a guidance for future energy-saving practices (FAO 2013).

\subsection{Social Dimension}

A total of 90 indicators were identified under the 'Social' dimension of sustainability (See Appendix D). A portion of these indicators could be grouped together into 11 indicators. These indicators were further categorized into their respective sustainability themes (See Table 6 and Table 7). These four themes include; labour rights, decent livelihood, equity as well as safety and health.

\subsubsection{Labour Rights and Safety and Health}

Six indicators; 'Child labour', 'Forced labour', 'Access to adequate protective equipment', 'Access to health care insurance', 'Access to potable water' and 'Number of worker incidences per year' were suggested under the labour rights and safety and health theme within the social dimension (See Table 6).

Table 6: Indicators suggested under the labour rights and safety and health theme within the social dimension

\begin{tabular}{|l|l|l|}
\hline \multicolumn{2}{|c|}{ Theme: Labour Rights and Safety and Health } \\
\hline \multicolumn{1}{|c|}{ Indicator } & \multicolumn{1}{c|}{ Measurement } & \multicolumn{1}{c|}{ References } \\
\hline Child labour & $\begin{array}{l}\text { Interviews with management and workers. } \\
\text { Reviewing company documents }\end{array}$ & FAO 2013; Van Eijck et al. 2014 \\
\hline Forced labour & $\begin{array}{l}\text { Interviews with management and workers. } \\
\text { Reviewing company documents }\end{array}$ & FAO 2013; Van Eijck et al. 2014 \\
\hline $\begin{array}{l}\text { Access to adequate } \\
\text { protective equipment }\end{array}$ & Measurements not mentioned & FAO 2013; FAO 2015 \\
\hline $\begin{array}{l}\text { Access to health care } \\
\text { insurance }\end{array}$ & Measurements not mentioned & COSA 2013; FAO 2013; FAO 2015 \\
\hline Access to potable water & Measurements not mentioned & COSA 2013; FAO 2015 \\
\hline $\begin{array}{l}\text { Number or worker } \\
\text { incidences per year }\end{array}$ & Measurements not mentioned & $\begin{array}{l}\text { COSA 2013; FAO 2015; Schweier } \text { et } \\
\text { al. 2018 }\end{array}$ \\
\hline
\end{tabular}


The indicator 'Child labour' refers to work that is harmful to the physical and mental development of children as well as deprives them of their childhood (FAO 2013). In today's capitalist system that strives for profits by reducing costs of inputs such as labour and capital, labour exploitation is an inherent and common risk (Marras 2003). Worldwide, more children are 'employed' in the agricultural sector compared to any other sector of the economy (Ramos 2018). Despite this high rate of employment, child labour issues within this sector remain relatively unaddressed (Lecours et al. 2012). This is due to a combination of factors namely; parents, employers, governments as well as weak national and international legal structures which continue to allow such practices to exist (Marlenga et al. 2007). As such, this indicator is essential to ensure that underaged 'workers' (children) are not employed and exploited by agricultural enterprises (FAO 2013).

However, only two studies were found to have tested this indicator (See Table 6). In the sampled articles, child labour activities were measured either by interviewing plantation workers and management as well as reviewing company documents and policies regarding child labour activities (FAO 2013; Van Eijck et al. 2014). A potential issue in the application of this indicator is that this indicator heavily relied on interviews and employment documentations to assess child labour issues within plantation systems (FAO 2013; Van Eijck et al. 2014). This can be problematic particularly within developing countries as employment records might not be available and the 'workers' (children) may be unwilling to provide details of their employment due to a variety of reasons such as the need for cash or family situation (Bales 2012).

The indicator 'Forced labour' refers to modern slavery in which workers are forced to work against their will, often in deplorable conditions with little to no pay (Gold, Trautrims \& Trodd 2015). Slavery or forced labour is fairly common within the plantation sector despite numerous laws prohibiting the practice (Chesney et al. 2019). One of the main reasons for this is due to the informal employment practices of this sector (Gold, Trautrims \& Trodd 2015). Most labourers within this sector are often promised reasonable pay and conditions without formal documentation (Gold, Trautrims \& Trodd 2015). In most cases, the promises are never fulfilled and as most of the labourers are illegal immigrants, the fear of deportation prevents most of them from voicing out against this injustice (Bales 2012). As such, this indicator is necessary to ensure that forced labour practices are not carried out within the enterprise (FAO 2013). 
However, only two studies were found to have tested this indicator (See Table 6). In the sampled articles, forced labour activities were measured either by interviewing plantation workers and management as well as reviewing company documents and policies regarding forced labour activities (FAO 2013; Van Eijck et al. 2014). Similar to the 'Child labour' indicator, the 'Forced labour' indicator also heavily relied on interviews and employment documentations to assess forced labour issues within plantation systems (FAO 2013; Van Eijck et al. 2014). This can again be problematic as employment records might not be available and the workers may be unwilling to provide details of their employment due to a variety of reasons such as the need for cash or fear of persecution or deportation (Bales 2012). Furthermore, the assessor whom verifies the forced labour issues must not only be able to speak the language of the employees but also be able to conduct interviews confidentially (FAO 2013).

The indicator 'Access to adequate protective equipment' refers to the provision of sufficient and adequate protective gear and safety equipment to the workers by the enterprise (FAO 2013). Plantation work exposes labourers to multiple hazards, particularly chemical hazards such as pesticides (McCurdy \& Carroll 2000). Pesticide exposure was the most cited hazard within the agricultural literature, with the World Health Organization (WHO) estimating that approximately 3 million cases of pesticide related intoxications are reported annually (McCurdy \& Carroll 2000; Ecobichon 2001; Villarejo 2003). Therefore, this indicator is necessary to ensure that agricultural labourers are provided with adequate protective equipment to minimize health and safety risks (Reddy et al. 2016).

However, the two studies that have mentioned this indicator have only prescribed it (See Table 6). As such, this indicator has not been tested. In the sampled articles, no specific methods to measure this indicator were stated (FAO 2013; FAO 2015). A potential issue in the application of this indicator is that compiling a list of essential gear and safety equipment that must be provided to the workers by the enterprise can be challenging (FAO 2013). This is because, the safety equipment provided must meet the standard requirements and regulations of the region as well as offer adequate protection against specified hazards (Karlson \& Noren 1979; FAO 2013). This can be problematic particularly within developing nations where safety and health issues are less regulated (Awwad et al. 2016). 
The indicator 'Access to health care insurance' refers to the health and medical care coverage provided to the workers by the enterprise (FAO 2013). Although the agricultural sector has progressed in reducing work related injuries and deaths through advancements in machinery, technology and better farming techniques, it still remains as one of the most dangerous industries in the world (McCurdy \& Carroll 2000). As such, this indicator is essential to ensure that workers have access to employer-provided protection particularly health care insurance (Shreck, Getz \& Feenstra 2006)

However, the three studies that have mentioned this indicator have only prescribed it (Table 6). As such, this indicator has not been tested. A potential issue in the application of this indicator is that assessing the coverage of the health care insurance provided by the enterprise to the workers can be difficult (FAO 2013). This is because, the health care insurance provided must meet both the local and regional laws as well as offer adequate protection depending on the type of work activities the workers are engaged in (FAO 2013). Unfortunately, this can be challenging to implement particularly within developing countries where safety and health issues are less regulated (Awwad et al. 2016).

The indicator 'Access to potable water' refers to whether workers have access to sufficient amounts of clean, drinking water for their hydration needs (FAO 2015). As most plantations are located within tropical regions and with plantation activities being highly strenuous, health risks such as heat stroke and dehydration are a serious concern (FAO 2013; Santika et al. 2019). Therefore, this indicator is required to ensure that workers are provided with sufficient amounts of clean, drinking water by the enterprise to prevent heat-related illnesses (Jackson \& Rosenberg 2010).

However, the two studies that have mentioned this indicator have only prescribed it (See Table 6). As such, this indicator has not been tested. In the sampled articles, no specific methods to measure this indicator were stated (COSA 2013; FAO 2015). A potential issue in the application of this indicator is that, simply providing enough potable water is insufficient to ensure adequate hydration (Jackson \& Rosenberg 2010). Workers often experience 'costs' of access to drinking water in the form of co-worker or supervisory disdain, foregone piece-work earnings as well as the physical effort to cover long distances (Jackson \& Rosenberg 2010). Therefore, potable water 
facilities should be kept close to work sites to encourage greater consumption (Jackson \& Rosenberg 2010).

The indicator 'Number of worker incidences per year' refers to the number of non-fatal worker incidences on the plantation within a year (FAO 2015). The unfavourable working conditions of some plantation systems as well as negligence among workers in developing nations contribute to the risk of occupational accidents (Naveen et al. 2013). This in turn, can increase the number of incidences on the plantation (Naveen et al. 2013). As such, this indicator is required to monitor trends in worker incidences in order to implement appropriate corrective measures to reduce the number or incidences (occupational accidents) over time (FAO 2015).

However, the three studies that have mentioned this indicator have only prescribed it (See Table 6). As such, this indicator has not been tested. In the sampled articles, no specific methods to measure this indicator were stated (COSA 2013; FAO 2015; Schweier et al. 2018). A potential issue in the application of this indicator is that it can be challenging to acquire a true estimate of the number of incidences that occur within the plantation system (Villarejo et al. 2010). This is because, the figures currently reported mostly include direct-hire employees and farm operators while seasonal or temporary labourers are excluded (Villarejo et al. 2010). Plantation agriculture relies on seasonal labour particularly during the harvest season to compensate for the additional workload (Bossen 1982). However, in most cases, these seasonal labourers are mostly undocumented (Bossen 1982). Furthermore, these labourers often never report farm-related incidences (injury or death) for fear of deportation and, in most cases must follow the harvest to the next crop to look for employment (McMahon 2002).

\subsubsection{Equity and Decent Livelihood}

Five indicators; 'Discrimination in employment', 'Gender wage differentials for the same quantity of work', 'Training for workers' 'Wage categories of employees' and 'Average working hours per week' were suggested under the equity and decent livelihood theme within the social dimension (See Table 7). 
Table 7: Indicators suggested under the equity and decent livelihood theme within the social dimension

\begin{tabular}{|l|l|l|}
\hline \multicolumn{3}{|c|}{ Theme: Equity and Decent Livelihood } \\
\hline \multicolumn{1}{|c|}{ Indicator } & \multicolumn{1}{|c|}{ Measurement } & \multicolumn{1}{c|}{ References } \\
\hline Discrimination in employment & $\begin{array}{l}\text { Document review and interviews with } \\
\text { workers and management }\end{array}$ & $\begin{array}{l}\text { Van Eijck } \text { et al. 2014; Prasara-A } \\
\text { \& Gheewala 2016 }\end{array}$ \\
\hline $\begin{array}{l}\text { Gender wage differentials for the same } \\
\text { quantity of work }\end{array}$ & $\begin{array}{l}\text { Document review and interviews with } \\
\text { workers and management }\end{array}$ & $\begin{array}{l}\text { FAO 2013; Prasara-A \& } \\
\text { Gheewala 2016 }\end{array}$ \\
\hline Training for workers & $\begin{array}{l}\text { Review company records. Interviews } \\
\text { with management }\end{array}$ & $\begin{array}{l}\text { Elfkih } \text { et al. 2012; Van Eijck et } \\
\text { al. 2014; Ingram } \text { et al. 2016 }\end{array}$ \\
\hline Wage categories of employees & $\begin{array}{l}\text { Review company records. Interviews } \\
\text { with workers and management }\end{array}$ & $\begin{array}{l}\text { FAO 2013; Van Eijck et al. 2014; } \\
\text { Prasara-A \& Gheewala 2016 }\end{array}$ \\
\hline Average working hours per week & $\begin{array}{l}\text { Review company records. } \\
\text { Interviews with workers and } \\
\text { management }\end{array}$ & $\begin{array}{l}\text { Van Eijck } \text { et al. 2014; Prasara-A } \\
\text { \& Gheewala 2016 }\end{array}$ \\
\hline
\end{tabular}

The indicator 'Discrimination in employment' refers to discriminatory practices particularly gender discrimination in employment opportunities (Prasara \& Gheewala 2016). Within agricultural systems, the most common discriminatory practice is gender differentials in employment opportunities as men are more likely to be employed compared to women particularly as permanent workers (Yaro, Teye \& Torvikey 2017). Besides this, agricultural systems are also largely patriarchal gendered system and as such, women tend to occupy lower positions compared to men (Apusigah 2009). As such, this indicator is essential to ensure that discriminatory practices regarding employment opportunities are not carried out (FAO 2013).

However, only two studies were found to have tested this indicator (See Table 7). In the sampled articles, discrimination in employment practices were measured either by interviewing plantation workers and management as well as reviewing company documents and policies regarding discriminatory activities (Van Eijck et al. 2014; Prasara-A \& Gheewala 2016). A potential issue in the application of this indicator is that, as this indicator heavily relied on interviews and employment documentations, this can be problematic as employment records might not be available particularly in developing countries and the female workers might not be willing to 
discuss any discriminatory practices due to a variety of reasons such as the need for cash, fear of persecution or harassment as well as family situation and needs (Bales 2012; Prasara \& Gheewala 2016). Furthermore, the assessor carrying out the assessment must also be familiar with the local language, customs, traditions and values of the region to carry out interviews and assessments effectively (FAO 2013).

The indicator 'Gender wage differentials for the same quantity of work' refers to whether both men and women are paid equally for the same or similar work (FAO 2013). Apart from employment opportunities, another common discriminatory practice is gender wage payments (Garikipati 2008; Yaro, Teye \& Torvikey 2017). It has been indicated that for some agricultural work such as harvesting and threshing, women are more preferred as they can be employed for lower wages compared to their male counterparts (Garikipati 2008). In some case, women are paid $30 \%$ less on average compared to their male colleagues for the same quantity of work (Yaro, Teye $\&$ Torvikey 2017). As such, this indicator is required to ensure that wages are paid fairly based on the type and quantity of work carried out irrespective of gender (FAO 2013).

However, only two studies were found to have tested this indicator (See Table 7). In the sampled articles, gender wage differentials were measured either by interviewing plantation workers and management as well as reviewing company documents and policies regarding discriminatory activities (FAO 2013; Prasara-A \& Gheewala 2016). Like the indicator 'Discrimination in employment', a potential issue in the application of this indicator is that, as this indicator heavily relied on interviews and employment documentations, this can be problematic as payment records might not be available particularly in developing countries and the workers might not be willing to discuss any discriminatory practices due to a variety of reasons such as the need for cash or fear of persecution (Bales 2012; Prasara \& Gheewala 2016).

The indicator 'Training for workers' refers to the necessary trainings that must be provided by the enterprise in order to equip the workers with the necessary skills to carry out the required task or activity efficiently and safely (FAO 2013). With the rise in the global demand for plantation commodities as well as climatic vulnerabilities (e.g. droughts, floods, unusual rainfall patterns), appropriate training for plantation workers is becoming more essential in order for plantation enterprises to ensure that their workforce is equipped with the necessary knowledge and skills to adapt to the changing environmental and global demands (FAO 2013; Gerber 2011; Alam et al. 
2012). As such, the performance of plantation systems in terms of crop production and yield largely depends on the type of training that is given to the workforce (Silici et al. 2011). This is because the appropriate training can ensure the coordinated and timely management of all farming activities which in turn influences the overall performance of the plantation (Silici et al. 2011).

However, only three studies were found to have tested this indicator (See Table 7). In the sampled articles, training for workers was measured either by interviewing plantation management as well as reviewing company documents and policies regarding training programs (Elfkih et al. 2012; Van Eijck et al. 2014; Ingram et al. 2016). A potential issue in the application of this indicator is that the training provided by plantation enterprises has been criticized as being mostly narrow (Lim \& Douglas 2000). This is because these training programs are often inherited from colonial structures which usually focuses solely on economic profitability with little consideration for environmental impacts (Grossman \& Iyigun 1995). Therefore, the training provided should not solely focus on crop yield and production but should also focus on wider issues of sustainable development such as natural resource management to ensure that the plantation can be managed more sustainably (Lim \& Douglas 2000).

The indicator 'Wage categories of employees' refers to whether workers are paid according to the standard wage laws of the region the enterprise operates in (Elfkih et al. 2012). Although plantation industries are often considered profitable agribusinesses that earn a foreign exchange, the profits generated by plantation industries do not necessarily reflect the income or wages paid to the workers (Hartemink 2005; Linton 2005). Leitner (1976) indicated that plantation workers are not only some of the most degraded workers particularly within developing countries but, their wages are also below subsistence. As such, this indicator is required to ensure that workers are paid accordingly based on the regional wage laws (FAO 2013).

However, only three studies were found to have tested this indicator (See Table 7). In the sampled articles, wage categories of employees were measured either by interviewing plantation management as well as reviewing company documents and policies regarding wage payments (FAO 2013; Van Eijck et al. 2014; Prasara-A \& Gheewala 2016). However, a potential issue in the application of this indicator is that the wages paid by the enterprise may not necessarily be consistent (Moretti \& Perloff 2002). Economic conditions (e.g. recession, market fluctuations) 
may temporarily prevent enterprises from paying a living wage which in turn can affect the livelihood of plantation workers whom are dependent on the day to day living wage (FAO 2013).

The indicator 'Average working hours per week' refers to the number of hours workers are expected to work on average within a given work week (Prasar \& Gheewala 2016). Mingorría et al. (2014) indicated that although plantation companies can provide additional income for plantation workers, some of these companies do overwork their workers. As such, some plantation companies can burden their workers with increasing labour and additional workload thereby preventing them from having adequate rest or other social activities (Mingorría et al. 2014). As such, this indicator is essential to ensure that workers have sufficient time for rest from work and to prevent workers from being overworked (FAO 2013).

However, only two studies were found to have tested this indicator (See Table 7). In the sampled articles, average working hours per week of employees were measured either by interviewing plantation management and workers as well as reviewing company documents and policies regarding working hours (Van Eijck et al. 2014; Prasara-A \& Gheewala 2016). A potential issue in the application of this indicator is that this indicator may not necessarily apply to all plantation workers especially seasonal workers whom are mostly undocumented (illegal immigrants) (Ecobichon 2001). As such, these workers may be subjected to more severe treatments including longer working hours due to the lack of regulations particularly within developing countries regarding labour laws (Bossen 1982).

\subsection{Economic Dimension}

A total of 60 indicators were identified under the 'Economic' dimension of sustainability (See Appendix D). These indicators were then grouped together into 15 indicators. These indicators were further categorized into their respective sustainability themes (See Table 8 and Table 9). These three themes include; investments, local economy and product quality.

\subsubsection{Investment}

Ten indicators; 'Overall farm revenue', 'Net Income', 'Profit', 'Crop Yield', 'Selling Price', 'Internal rate of return', 'Net Present Value', 'Gross Margin', 'Internal Investment' and 
'Production Costs' were suggested under the investment theme within the economic dimension (See Table 8).

Table 8: Indicators suggested under the investment theme within the economic dimension

\begin{tabular}{|c|c|c|}
\hline \multicolumn{3}{|c|}{ Theme: Investment } \\
\hline Indicator & Measurement & References \\
\hline Overall farm revenue & $\begin{array}{l}\text { Interviews with management. Review } \\
\text { company records }\end{array}$ & $\begin{array}{l}\text { Fleskens et al. 2009; Chopin et al. 2015; } \\
\text { Sun et al. 2017; Rodrigues et al.2018 }\end{array}$ \\
\hline Net Income & $\begin{array}{l}\text { Review the income statement of the } \\
\text { organization }\end{array}$ & COSA 2013; FAO 2013 \\
\hline Profit & Farm surveys. Interviews. & $\begin{array}{l}\text { Gómez-Limón \& Riesgo 2009; Testa et al. } \\
\text { 2015; Ingram et al. 2016; Sun et al. } 2017\end{array}$ \\
\hline Crop Yield & Interviews or focus group discussions & $\begin{array}{l}\text { Pretty et al. 2008; Sydorovych et al. 2009; } \\
\text { Rodrigues et al. } 2018\end{array}$ \\
\hline Selling Price & $\begin{array}{l}\text { Document review or interviews with } \\
\text { management }\end{array}$ & Fleskens et al. 2009; Rodrigues et al. 2018 \\
\hline Internal rate of return & Review company documents & $\begin{array}{l}\text { Van Eijck et al. 2014; Testa } \text { et al. 2015; Sun } \\
\text { et al. } 2017\end{array}$ \\
\hline Net Present Value & Review company documents & $\begin{array}{l}\text { Giménez et al. 2013; Van Eijck et al. 2014; } \\
\text { Yi et al. 2014; Testa et al. 2015; Diaz- } \\
\text { Balteiro et al. 2016; Sun et al. } 2017\end{array}$ \\
\hline Gross margin & Farm survey & $\begin{array}{l}\text { Gómez-Limón \& Riesgo 2009; Dantsis et } \\
\text { al. } 2010\end{array}$ \\
\hline Internal Investment & Review company records & FAO 2013; FAO 2015 \\
\hline Production Costs & Review company records & $\begin{array}{l}\text { Fleskens et al. 2009; Van Eijck et al. 2014; } \\
\text { Schweier } \text { et al. } 2018\end{array}$ \\
\hline
\end{tabular}

The indicator 'Overall farm revenue' refers to the total income generated from the normal business operations of the enterprise (plantation company) before subtracting costs (Chopin et al. 2015). Farm revenue is an essential indicator of economic sustainability in order to track the financial performance of the enterprise from year to year (Chopin et al. 2015). Generally, enterprises' whose revenues increase over time have better financial performance compared to those whose revenues remain the same or decrease over time (Rai et al. 2006).

A total of four studies were found to have tested this indicator (See Table 8). In the sample articles, overall farm revenue was measured either by interviewing plantation management or reviewing company financial records regarding business performance (Fleskens et al. 2009; Chopin et al. 2015; Sun et al. 2017). A potential issue in the application of this indicator is that this indicator cannot be used as a stand-alone indicator and must be combined with other indicators such as 'Production Costs' and 'Selling Price' to provide a true picture of the financial performance of the 
enterprise (FAO 2013). This is because this indicator has not accounted for the production and operational costs of the enterprise which is required to provide a true picture of profitability (FAO 2013).

The indicator 'Net Income' refers to the income of the enterprise after accounting for additional costs including business expenses and taxes (FAO 2013). It is a useful indicator for businesses to assess how much revenue exceeds the costs of a business (Hitt et al. 2002). However, the two studies that have mentioned this indicator have only prescribed it (See Table 8). As such, this indicator has not been tested. The legitimacy of this indicator was found to be medium as two stakeholder groups (UN institutions and NGOs) have prescribed this indicator. In the sampled articles, net income was measured by reviewing company financial records regarding business performance (COSA 2013; FAO 2013). Similar to the 'Overall farm revenue' indicator, this indicator also requires other indicators such as 'Return on Equity' and 'Earnings per Share' to provide a true picture on the actual income and profitability of the enterprise (FAO 2013).

The indicator 'Profit' refers to the financial benefits realized when the revenue generated through the enterprise's operations exceeds the expenses, taxes and costs involved in sustaining the operations and activities of the business (Gómez-Limón \& Riesgo 2009). This indicator is essential to measure the long-term profitability of the enterprise thereby allowing the enterprise to determine which operations must be increased or reduced to generate, maintain and increase the enterprise's long-term profits (FAO 2013).

A total of four studies were found to have tested this indicator (See Table 8). In the sampled articles, profit was measured either by interviewing plantation management or surveying different farmers regarding the profits generated through the operational activities of the enterprise (GómezLimón \& Riesgo 2009; Testa et al. 2015; Sun et al. 2017). A potential issue in the application of this indicator is that the type of profit measured was not stated in all the mentioned studies. This can be problematic as different types of profits (e.g. Gross Profit, Operating Profit and Net Profit) provide assessors with different information regarding the enterprise's performance (FAO 2013). This is essential when comparing the enterprise's performance to other competitors within the same time period (FAO 2013).

The indicator 'Crop Yield' refers to the total quantity of crops produced by the enterprise for sale (e.g. export) within a given time period (Sydorovych et al. 2009; Rodrigues et al. 2018). This 
indictor is essential as crop yield greatly influences the revenue and subsequently the profit of the enterprise as higher yields generally results in higher financial returns (Pretty et al. 2008; Rodrigues et al. 2018).

However, only three studies were found to have tested this indicator (See Table 8). In the sampled articles, crop yield was measured either by interviewing plantation management or through focus group discussions with farmers regarding the annual crop yields of the plantation (Pretty et al. 2008; Sydorovych et al. 2009; Rodrigues et al. 2018). A potential issue in the application of this indicator is that the quality of the crops produced also plays a role in terms of financial returns as higher quality crops can be sold at a higher selling price (FAO 2013). As such, this indicator must be paired with other indicators such as 'Crop Quality' and 'Selling Price' to accurately determine the financials returns of the enterprise (FAO 2013; Rodrigues et al. 2018).

The indicator 'Selling Price' refers to the price at which the products (e.g. crops) of the enterprise are sold for (Rodrigues et al. 2018). The selling price is essential in ensuring that the products are not only sold above the break-even point but, the price of the products have also been marked up to ensure that enterprise makes a profit (FAO 2013).

However, only two studies were found to have tested this indicator (See Table 8). In the sample articles, selling price was measured either by interviewing plantation management or reviewing company financial records regarding business performance (Fleskens et al. 2009; Rodrigues et al. 2018). A potential issue in the application of this indicator is that this indicator is dependent on other factors such as market stability and supply demands (FAO 2013). This is because market stability and supply demands can be influenced by issues such as customer behaviour, global pandemic as well as natural disasters which in turn can influence the selling price of the products and subsequently the profits generated as well (FAO 2013).

The indicator 'Internal rate of return' is an economic metric that is used to estimate the profitability of potential investments of the enterprise (Testa et al. 2015). As such, this indicator is essential for businesses to plan future growth and investments (Van Eijck et al. 2014). However, only three studies were found to have tested this indicator (See Table 8). In the sampled articles, internal rate of return was measured by reviewing company financial records regarding business performance (Van Eijck et al. 2014; Testa et al. 2015; Sun et al. 2017). A potential issue in the application of 
this indicator is that this indicator is technical and requires prior financial and investment knowledge to understand and utilize accurately (Juhász 2011).

The indicator 'Net Present Value' is used to evaluate the projected earnings of the enterprise's activities in present time/day (Sun et al. 2017). Based on this indicator, activities that have a positive NPV will be profitable and those with a negative NPV will generate a loss (Sun et al. 2017). The 'Net Present Value' indicator is also essential in estimating the profitability of potential investments and is often used together with the 'Internal rate of return' indicator (Testa et al. 2015; Sun et al. 2017).

A total of six studies were found to have tested this indicator (See Table 8). In the sampled articles, net present value was measured by reviewing company financial records regarding business performance (Giménez et al. 2013; Van Eijck et al. 2014; Yi et al. 2014). Similar to the indicator 'Internal rate of return', this indicator is also technical and requires prior financial and investment knowledge to understand and utilize accurately (Juhász 2011; Sun et al. 2017).

Within agricultural systems, the indicator 'Gross margin' refers to the difference between the gross agricultural value and a variable crops cost (e.g. seeds, pesticides, fertilizers) (Dantsis et al. 2010). However, as the costs do not include fixed assets and labour costs, this indicator is only useful for measuring the profitability of the enterprise in the short term and not the long term (Gómez-Limón \& Riesgo 2009). As such, this indicator is not as essential in measuring the profitability of the plantation agricultural systems compared to the other listed indicators.

However, only two studies were found to have tested this indicator (See Table 8). In the sampled articles, this indicator was measured by surveying different farmers regarding the gross margin value per year of different farms (Gómez-Limón \& Riesgo 2009; Dantsis et al. 2010). A potential issue in the application of this indicator is that this indicator does not provide a true measure of profitability as it does not include costs such as interests, taxes and other relevant expenses (Gómez-Limón \& Riesgo 2009; Dantsis et al. 2010).

The indicator 'Internal Investment' refers to the investments made by the enterprise to improve its environmental, social, governance and economic performance (FAO 2013). As such, this indicator is essential to ensure that the enterprise has implemented essential investments into its internal structure to ensure the long-term sustainability of the enterprise (FAO 2013). However, the two 
studies that have mentioned this indicator have only prescribed it (See Table 8). As such, this indicator has not been tested. In the sampled articles, this indicator was measured by reviewing company financial records regarding business performance and investments (FAO 2013; FAO 2015). A potential issue in the application of this indicator is that this indicator does not measure if the practices implemented by the enterprise have successfully improved the enterprise's sustainability performance (FAO 2013). As such, this indicator does not guarantee progress in sustainability and should just be taken as the enterprise's initial step towards improvements in sustainability performance (FAO 2013).

The indicator 'Production Costs' is a comprehensive performance and accounting indicator that is essential to make business decision plans particularly investment plans (FAO 2013). Some of these investments include mechanization and use of green technology to reduce both labour and power costs respectively (Strijker 2005; Huang et al. 2013). As such, this indicator is essential to determine which investments are required within its supply chain to reduce costs in order to lower its product price and to make it more competitive (Klassen \& McLaughlin 1996).

However, only three studies were found to have tested this indicator (See Table 8). In the sampled articles, this indicator was measured by reviewing company financial records regarding business performance and investments (Fleskens et al. 2009; Van Eijck et al. 2014; Schweier et al. 2018). A potential issue in the application of this indicator is that the accounting practices to measure production costs must be adapted over time to meet the changing needs and plans of the enterprise over time (FAO 2013).

\subsubsection{Local Economy and Product Quality}

Five indicators; 'Agricultural employment', 'Type of pesticide applied', 'Use of pest resistant cultivar', 'Amount of pesticide used' and Integrated pest management plan' were suggested under the local economy and product quality theme within the economic dimension (Table 9). 
Table 9: Indicators suggested under the local economy and product quality theme within the economic dimension

\begin{tabular}{|c|c|c|}
\hline \multicolumn{3}{|c|}{ Theme: Local Economy and Product Quality } \\
\hline Indicator & Measurement & References \\
\hline Agricultural Employment & $\begin{array}{l}\text { Company employment records. } \\
\text { Interviews with communities }\end{array}$ & $\begin{array}{l}\text { Dantsis et al. 2010; Elfkih et al. 2012; } \\
\text { Van Eijck et al. 2014; Munyanduki et } \\
\text { al. 2016; Sun et al. 2017; Schweier et } \\
\text { al. } 2018\end{array}$ \\
\hline Types of pesticide applied & $\begin{array}{l}\text { No of replication used per growing } \\
\text { season per pesticide. Data obtained } \\
\text { through survey of farm area. }\end{array}$ & $\begin{array}{l}\text { Pretty et al. 2008; Dantsis et al. 2010; } \\
\text { Elfkih et al. 2012; FAO 2015; Chopin } \\
\text { et al. } 2016\end{array}$ \\
\hline Use of pest resistant cultivar & Farm survey & FAO 2015; Chopin et al. 2016 \\
\hline Amount of pesticide used & Measurements not mentioned & Pretty et al. 2008; COSA 2013 \\
\hline $\begin{array}{l}\text { Integrated Pest Management } \\
\text { Plan }\end{array}$ & $\begin{array}{l}\text { Data obtained through interviews and } \\
\text { questionnaires. }\end{array}$ & $\begin{array}{l}\text { COSA 2013; Thivierge et al. 2014; } \\
\text { FAO } 2015\end{array}$ \\
\hline
\end{tabular}

The indicator 'Agricultural Employment' refers to the level of employment provided by the enterprise within the plantation agricultural system (Dantsis et al. 2010). Agribusinesses particularly plantation agriculture are usually associated with job creation (Charnley 2006). This is because, these agribusinesses typically employ a relatively large number of unskilled labourers thereby contributing to the local economic development of a region (Hartemink 2005). This is particularly relevant for the sustainable development of rural areas (FAO 2013). Therefore, agribusinesses like plantations are in a good position to contribute to the local economic development of rural areas where value creation is highly required (Charnley 2006).

A total of six studies were found to have tested this indicator (See Table 9). In the sampled articles, this indicator was measured either by reviewing company employment records or interviewing local communities regarding the employment opportunities provided by the enterprise (Dantsis et al. 2010; Elfkih et al. 2012; Van Eijck et al. 2014). A potential issue in the application of this indicator is that jobs associated with the plantation sector are more frequently being given to outsiders rather than to local/rural residents (Charnley 2006). As such, the origin of the workers 
should also be considered to measure the number of non-regional employees hired and justification should also be provided regarding the use of non-local labour (FAO 2013; Van Eijck et al. 2014). The indicator 'Type of pesticide applied' refers to the type of pesticides applied on the crops within the plantation agricultural system (Chopin et al. 2016). Agricultural products can become contaminated within the supply chain through a variety of ways including through the use of chemicals such as pesticides (COSA 2013). Some of these pesticides are highly hazardous as they can cause a variety of health effects in humans even at low exposure levels (FAO 2013). As such, the type of pesticide applied can affect the quality of the crops produced (FAO 2013).

A total of five studies were found to have tested this indicator (See Table 9). In the sampled articles, this indicator was tested by surveying farmers regarding the number of replications used per growing season per pesticide (Pretty et al. 2008; Dantsis et al.2010; Elfkih et al. 2012). A potential issue in the application of this indicator is that the data on the type of pesticides applied or approved for use might not be available particularly within developing nations (FAO 2013).

The indicator 'Use of pest resistant cultivar' refers to the use of crops which have a reduced susceptibility to certain pest populations (Chopin et al. 2016). These crops have been genetically modified and are usually toxic to some pest (e.g. insects) populations (Dawson et al. 1989). The use of these pest resistant crops (cultivars) can help reduce the use and dependence on chemicals such as pesticides which can affect crop quality and subsequently human health as well (FAO 2013).

However, only two studies were found to have tested this indicator (See Table 9). In the sampled articles, this indicator was measured through farm surveys (FAO 2015; Chopin et al. 2016). A potential issue in the application of this indicator is that, as this indicator is not widely prevalent it may lack legitimacy among other stakeholder groups such as NGOs' whom may refuse to adopt this indicator (Aerni 2005). Aerni (2005) indicated that while some stakeholder groups such as agribusinesses and government organizations believe in the benefits of pest resistant crops (GM crops), other stakeholder groups such as some NGOs are more hesitant.

The indicator 'Amount of pesticide used' refers to the amount of pesticides applied on the crops within the plantation agricultural system (Pretty et al. 2008). Chemical pesticides are often used in excess within developing nations to reduce endemic as well as insect-borne diseases (Ecobichon 
2001). The excessive use and sometimes misuse of these pesticides often create serious health problems as well as local and global environmental pollution (Ecobichon 2001). Therefore, this indicator is essential to ensure that the guidelines regarding the application quantity of the pesticides are adhered to.

However, only two studies were found to have tested this indicator (See Table 9). In the sampled articles, no specific methods to measure this indicator were stated (Pretty et al. 2008; COSA 2013). A potential issue in the application of this indicator is that the lack of rigorous regulations and legislation to control pesticide use particularly within developing nations can make it challenging for assessors to inspect and monitor pesticide use (Ecobichon 2001).

The indicator 'Integrated Pest Management Plan' refers to the activities carried out by the enterprise to reduce reliance on chemical usage and increase reliance on eco-friendly pest management methods (e.g. biocontrol) (Thivierge et al. 2014). Concerns over the type of pesticides used and their impacts on agricultural crops as well as the subsequent effects on the health of consumers have prompted various actor groups to recommend the use of integrated pest management (IPM) plans (Pretty et al. 2008).

However, only three studies were found to have tested this indicator (See Table 9). In the sampled articles, this indicator was measured using questionnaires as well as interviews with plantation management regarding the use of IPM plans (COSA 2013; Thivierge et al. 2014; FAO 2015). A potential issue in the application of this indicator is that it can be difficult to directly measure the effectiveness of each activity within the IPM plan in terms of pest control (FAO 2013).

\subsection{Governance Dimension}

A total of 14 indicators were identified under the 'Governance' dimension of sustainability (See Appendix D). These indicators were then grouped together into 3 indicators. These indicators were further categorized into their respective sustainability themes (See Table 10). These two themes include; Transparency and Stakeholder participation. 


\subsubsection{Transparency and Stakeholder Participation}

Table 10: Indicators suggested under the transparency and stakeholder participation theme within the governance dimension

\begin{tabular}{|l|l|l|}
\hline \multicolumn{3}{|c|}{ Theme: Transparency and Stakeholder Participation } \\
\hline \multicolumn{1}{|c|}{ Indicator } & \multicolumn{1}{|c|}{ Measurement } & \multicolumn{1}{c|}{ References } \\
\hline Transparency & $\begin{array}{l}\text { Review company documents and } \\
\text { policy }\end{array}$ & $\begin{array}{l}\text { FAO 2013; Van Eijck et al. } \\
2014\end{array}$ \\
\hline $\begin{array}{l}\text { Implementation of stakeholder } \\
\text { engagement strategies }\end{array}$ & $\begin{array}{l}\text { Interviews with plantation } \\
\text { management and workers }\end{array}$ & $\begin{array}{l}\text { FAO 2013; Ingram et al. } \\
2016\end{array}$ \\
\hline $\begin{array}{l}\text { Participation of stakeholders in } \\
\text { plantation activities }\end{array}$ & Interview plantation management & FAO 2013; FAO 2015 \\
\hline
\end{tabular}

The indicator 'Transparency' refers to whether the enterprise provides information regarding its business operations to the relevant stakeholders in a complete and accessible manner (FAO 2013). Over the past few years, stakeholders have been putting increasing accountability pressures on multinational companies due to suspicions about the environmental and social implications of the business operations of these enterprises within different markets (Cooper \& Owen 2007; Kolk 2008). As such, this indicator is essential to ensure that relevant stakeholders are provided with essential information about the enterprise's operations thereby allowing them to make more appropriate decisions (FAO 2013).

However, only two studies were found to have tested this indicator (See Table 10). In the sampled articles, this indicator was measured by reviewing company records and policies regarding business transparency (FAO 2013; Van Eijck et al. 2014). A potential issue in the application of this indicator is that the articles that mentioned this indicator did not state the guidelines regarding which information was deemed relevant to be disclosed as well as how much information to disclose to different stakeholders (FAO 2013; Van Eijck et al. 2014). For example, shareholders require information regarding the firm's financial health while community and regulatory stakeholders require information of the firm's sustainability-friendly practices (Wu et al. 2019). 
The type and amount of information disclosed is essential as a careful balance is required to satisfy the information requirement needs of different stakeholders (Wu et al. 2019).

The indicator 'Implementation of stakeholder engagement strategies' refers to the engagement strategies utilized by the enterprise to engage with different groups of relevant stakeholders (FAO 2013). Stakeholder engagement is essential for plantation enterprises to comprehend the needs and interests of various stakeholders in order to make informed decisions as well as the potential risks of those decisions (Roome 2005).

However, only two studies were found to have tested this indicator (See Table 10). In the sampled articles, this indicator was measured by interviewing plantation management and workers regarding the different engagement strategies utilized (FAO 2013; Ingram et al. 2016). A potential issue in the application of this indicator is that engaging with different stakeholders might be difficult due to the various engagement barriers with different stakeholders in different regions (FAO 2013). Furthermore, in developing regions, regulations and laws regarding effective engagement with different stakeholder groups may not be strictly enforced (FAO 2013). As such, enterprises may be less willing to engage and acquire feedback particularly from rural stakeholders regarding the decision strategies implemented by the enterprise thereby marginalizing some stakeholder groups and potentially causing further conflicts in the future (Obidzinski et al. 2012).

The indicator 'Participation of stakeholders in plantation activities' refers to the ways the enterprise incorporated the views of different stakeholders in any decisions made (FAO 2013). This indicator is essential to help facilitate mutual learning and negotiations regarding the decisions made as well as avoid potential conflicts regarding business decisions among different stakeholder groups (Meppem 2000; Leventon et al. 2016; Santoso \& Delima 2017).

However, the two studies that have mentioned this indicator have only prescribed it (See Table 10). As such, this indicator has not been tested. In the sampled articles, this indicator was measured by interviewing plantation management regarding the different decisions that have been made in response to the input from different stakeholders (FAO 2013; FAO 2015). A potential issue in the application of this indicator is that it can be challenging to confirm if the views of the stakeholders have actually influenced the decisions made by the enterprise (FAO 2013). 


\section{Conclusions}

The main aim of this study was to identify a suite of indicators that can be used to assess the sustainability of plantation agricultural systems. Through our research we managed to identify 47 common indicators covering the four sustainability dimensions - environmental, social, economic and governance within the UNCSD framework.

Although it was possible to identify relevant indicators to assess the sustainability of plantation agricultural systems, it was difficult to conclusively identify a universal set of relevant indicators. This is unsurprising as the definition of 'sustainability' is dependent not only on local conditions but stakeholders as well (Bell \& Morse 2008). As such, it was challenging to find a universal set of indicators that is not only applicable across different geographic regions but also accepted by different stakeholder groups. Furthermore, as indicated in this paper, each of the identified indicators have different potential application issues. Most of these issues often relate to complexity of use, lack of data as well as vague guidelines regarding the use of the indicators.

These issues can affect their subsequent utilization by different stakeholder groups. As such, when selecting sustainability indicators for use, a careful balance between simplicity of use as well as clarity and efficiency of the selected sustainability indicator is required. Therefore, both a 'one size fits all' and 'top down' approach might not be the most effective way to select relevant indicators to assess the sustainability of plantation systems as both these approaches have been known to restrict the number of factors (e.g. social factors) taken into consideration during the selection process.

We conclude by arguing that the selection of sustainability indicators for plantation agriculture must take a more 'tailored' approach (i.e. bottom up and participatory based approach) to address the different opinions and concerns of various stakeholder groups. As such, we argue that future research must place more emphasis on the participation and engagement of diverse and relevant stakeholder groups in order to select a universal set of sustainability indicators for plantation agriculture that can be widely accepted. Through this approach, a set of indicators that are simple, 
widely accepted and effective in assessing the sustainability of plantation agricultural systems can be developed.

\section{References}

Ayars, J.E., Phene, C.J., Hutmacher, R.B., Davis, K.R., Schoneman, R.A., Vail, S.S., \& Mead, R.M., 1999. Subsurface drip irrigation of row crops: a review of 15 years of research at the Water Management Research Laboratory. Agricultural water management, 42 (1), pp.1-27.

Andrews, S.S., \& Carroll, C.R., 2001. Designing a soil quality assessment tool for sustainable agroecosystem management. Ecological Applications, 11 (6), pp. 1573-1585.

Aerni, P., 2005. Stakeholder attitudes towards the risks and benefits of genetically modified crops in South Africa. Environmental Science \& Policy, 8 (5), pp. 464-476.

Al-Omran, A.M., Sheta, A.S., Falatah, A.M. \& Al-Harbi, A.R., 2005. Effect of drip irrigation on squash (Cucurbita pepo) yield and water-use efficiency in sandy calcareous soils amended with clay deposits. Agricultural water management, 73 (1), pp. 43-55.

Alston, J.M., Beddow, J.M. \& Pardey, P.G., 2009. Agricultural research, productivity, and food prices in the long run. Science, 325 (5945), pp. 1209-1210.

Apusigah, A.A., 2009. The gendered politics of farm household production and the shaping of women's livelihoods in Northern Ghana. Feminist Africa, 12 (12), pp. 51-67.

Agudelo-Suárez, A., Gil-Gonzalez, D., Ronda-Perez, E., Porthe, V., Paramio-Perez, G., García, A.M. \& Garí, A., 2009. Discrimination, work and health in immigrant populations in Spain. Social science \& medicine, 68 (10), pp. 1866-1874.

Aizen, M.A., Garibaldi, L.A., Cunningham, S.A., \& Klein, A.M., 2009. How much does agriculture depend on pollinators? Lessons from long-term trends in crop production. Annals of botany, 103 (9), pp. 1579-1588. 
Alkan Olsson, J., Bockstaller, C., Stapleton, L.M., Ewert, F., Knapen, R., Therond, O., Geniaux, G., Bellon, S., Correira, T.P., Turpin, N., \& Bezlepkina, I., 2009. A goal oriented indicator framework to support integrated assessment of new policies for agri-environmental systems. Environmental Science and Policy, 12 (5), pp. 562-572.

Ariza-Montobbio, P. \& Lele, S., 2010. Jatropha plantations for biodiesel in Tamil Nadu, India: Viability, livelihood trade-offs, and latent conflict. Ecological Economics, 70 (2), pp. 189-195.

Alam, M.M., Siwar, C., Molla, R.I., Talib, B. \& bin Toriman, M.E., 2012. Paddy farmers' adaptation practices to climatic vulnerabilities in Malaysia. Mitigation and Adaptation Strategies for Global Change, 17 (4), pp. 415-423.

Awwad, R., El Souki, O. \& Jabbour, M., 2016. Construction safety practices and challenges in a Middle Eastern developing country. Safety science, 83 (1), pp.1-11.

Bossen, L., 1982. Plantations and labour force discrimination in Guatemala. Current anthropology, 23 (3), pp. 263-268.

Banaszak, J., 1992. Strategy for conservation of wild bees in an agricultural landscape. Agriculture, ecosystems \& environment, 40 (1-4), pp. 179-192.

Brubaker, S.C., Jones, A.J., Lewis, D.T. \& Frank, K., 1993. Soil properties associated with landscape position. Soil Science Society of America Journal, 57 (1), pp. 235-239.

Byard, R., Lewis, K.C. \& Montagnini, F., 1996. Leaf litter decomposition and mulch performance from mixed and monospecific plantations of native tree species in Costa Rica. Agriculture, ecosystems \& environment, 58 (2-3), pp. 145-155.

Bittermann, W., \& Haberl, H., 1998. Landscape-relevant indicators for pressures on the environment. Innovation, 11 (1), pp. 87-106. 
Bouma, J., Batjes, N.H., \& Groot, J.J.R., 1998. Exploring land quality effects on world food supply. Geoderma, 86 (1-2), pp. 43-59.

Barlow, K. \& Cocklin, C., 2003. Reconstructing rurality and community: plantation forestry in Victoria, Australia. Journal of Rural Studies, 19 (4), pp. 503-519.

Braun, V., \& Clarke, V., 2006. Using thematic analysis in psychology. Qualitative Research in Psychology, 3 (2). pp. 77-101.

Byron Houser, J., \& Pitt, R., 2008. Simulation of soil loss and available water content to assess the sustainability of selected farm practices. Journal of Sustainable Agriculture, 32 (3), pp. 507-527.

Bell, S., \& Morse, S., 2008. Sustainability indicators: measuring the immeasurable. U.K: Earthscan.

Brunner, A.C., Park, S.J., Ruecker, G.R. \& Vlek, P.L.G., 2008. Erosion Modelling Approach to Simulate the Effect of Land Management Options on Soil Loss by Considering Catenary Soil Development and Farmers Perception. Land Degradation \& Development, 19 (6), pp. 623-635.

Ban, N.C., Hansen, G.J., Jones, M. \& Vincent, A.C., 2009. Systematic marine conservation planning in data-poor regions: socioeconomic data is essential. Marine Policy, 33 (5), pp. 794800.

Bouajila, A., \& Gallali, T., 2010. Land use effect on soil and particulate organic carbon, and aggregate stability in some soils in Tunisia. African Journal of Agricultural Research, 5 (8), pp. 764-774.

Bonilla, S.H., Guarnetti, R.L., Almeida, C.M.V.B. \& Giannetti, B.F., 2010. Sustainability assessment of a giant bamboo plantation in Brazil: exploring the influence of labour, time and space. Journal of Cleaner Production, 18 (1), pp. 83-91.

Bales, K., 2012. Disposable People: New Slavery in the Global Economy. U.S: University of California Press. 
Biswas, S., Ali, M.N., Goswami, R., \& Chakraborty, S., 2014. Soil health sustainability and organic farming: A review. Journal of Food, Agriculture and Environment, 12 (3-4), pp. 237-243.

Béné, C., Barange, M., Subasinghe, R., Pinstrup-Andersen, P., Merino, G., Hemre, G.I. \& Williams, M., 2015. Feeding 9 billion by 2050 - Putting fish back on the menu. Food Security, 7 (2), pp. 261-274.

Bellamy, A.S., Svensson, O., van den Brink, P.J. \& Tedengren, M., 2016. What is in a label? Rainforest-Alliance certified banana production versus non-certified conventional banana production. Global Ecology and Conservation, 7 (1), pp. 39-48.

Bhatt, R., Kukal, S.S., Busari, M.A., Arora, S. \& Yadav, M., 2016. Sustainability issues on ricewheat cropping system. International Soil and Water Conservation Research, 4 (1), pp. 64-74.

Boiral, O. \& Heras-Saizarbitoria, I., 2017. Managing biodiversity through stakeholder involvement: why, who, and for what initiatives?. Journal of Business Ethics, 140 (3), pp.403-421.

Bissonnette, J., \& De Koninck, R., 2017. Social and Environmental Implications of Plantation Agricculture in Malaysia and Indonesia. Oxford Research Encyclopedia of Environmental Science [online], (February), pp. 1-31. DOI: 10.1093/acrefore/9780199389414.013.207 [Accessed 25 April 2018]

Biswas, J.C. \& Naher, U.A., 2019. Advances in Rice Research for Abiotic Stress Tolerance. U.S: Woodhead Publishing.

Clement, C. R., \& Williams, E. T., 1967. Leys and soil organic matter II. The accumulation of nitrogen in soils under different leys. Journal of Agricultural Science, 59 (1), pp. 133-138.

Cleveland, C.J., 1995. The direct and indirect use of fossil fuels and electricity in USA agriculture, 1910-1990. Agriculture, Ecosystems \& Environment, 55 (2), pp. 111-121.

CIFOR., 1999. The Criteria \& Indicators Toolbox Series. Indonesia: CIFOR. 
Christopher, M. \& Peck, H., 2004. Building the resilient supply chain. The international journal of logistics management, 15 (2), pp. 1-14.

Cachon, G.P. \& Lariviere, M.A., 2005. Supply chain coordination with revenue-sharing contracts: strengths and limitations. Management science, 51 (1), pp. 30-44.

Common, M. \& Stagl, S., 2005. Ecological Economics - An Introduction. Cambridge: Cambridge University Press

Charnley, S., 2006. Industrial plantation forestry: Do local communities benefit?. Journal of Sustainable Forestry, 21 (4), pp. 35-57.

Chacoff, N.P., \& Aizen, M.A., 2006. Edge effects on flower-visiting insects in grapefruit plantations bordering premontane subtropical forest. Journal of Applied Ecology, 43 (1), pp.1827.

Cooper, S.M. \& Owen, D.L., 2007. Corporate social reporting and stakeholder accountability: The missing link. Accounting, Organizations and Society, 32 (7-8), pp. 649-667.

Craighead, C.W., Blackhurst, J., Rungtusanatham, M.J. \& Handfield, R.B., 2007. The severity of supply chain disruptions: design characteristics and mitigation capabilities. Decision Sciences, 38 (1), pp. 131-156.

Chel, A., \& Kaushik, G., 2011. Renewable energy for sustainable agriculture. Agronomy for Sustainable Development, 31 (1), pp. 91-118.

COSA., 2013. The COSA Measuring Sustainability Report: Coffee and Cocoa in 12 Countries. Philadelphia: COSA.

Coote, L., Dietzsch, A.C., Wilson, M.W., Graham, C.T., Fuller, L., Walsh, A.T., Irwin, S., Kelly, D.L., Mitchell, F.J.G., Kelly, T.C. \& O’Halloran, J., 2013. Testing indicators of biodiversity for plantation forests. Ecological Indicators, 32 (1), pp. 107-115. 
Chopin, P., Doré, T., Guindé, L. \& Blazy, J.-., 2015. MOSAICA: A multi-scale bioeconomic model for the design and ex ante assessment of cropping system mosaics. Agricultural Systems, 140 (10), pp. 26-39

Chopin, P., Tirolien, J. \& Blazy, J., 2016. Ex-ante sustainability assessment of cleaner banana production systems. Journal of Cleaner Production, 139 (1), pp. 15-24.

Chandran et al., 2019. Organic Farming: Global Perspective and Methods. Cambridge: Woodhead Publishing.

Chesney, T., Evans, K., Gold, S., \& Trautrims, A., 2019. Understanding labour exploitation in the Spanish agricultural sector using an agent based approach. Journal of Cleaner Production, 214 (2019), pp. 696-704.

Dawson, G.W., Hallahan, D.L., Mudd, A., Patel, M.M., Pickett, J.A., Wadhams, L.J. \& Wallsgrove, R.M., 1989. Secondary plant metabolites as targets for genetic modification of crop plants for pest resistance. Pesticide science, 27 (2), pp. 191-201.

Dalal, R. C., 1998. Soil microbial biomass-what do the numbers really mean? Australian Journal of Experimental Agriculture, 38 (1), pp. 649-665.

Duelli, P., Obrist, M.K., \& Schmatz, D.R., 1999. Biodiversity evaluation in agricultural landscapes: above-ground insects. Agriculture, Ecosystems \& Environment, 74 (1-3), pp. 33-64.

Dunn, B.W., Batten, G.D., Beecher, H.G. \& Ciavarella, S., 2002. The potential of near-infrared reflectance spectroscopy for soil analysis - a case study from the Riverine Plain of south-eastern Australia. Australian Journal of Experimental Agriculture, 42 (5), pp. 607-614.

DeFries, R., Achard, F., Brown, S., Herold, M., Murdiyarso, D., Schlamadinger, B. \& de Souza Jr, C., 2007. Earth observations for estimating greenhouse gas emissions from deforestation in developing countries. Environmental science \& policy, 10 (4), pp. 385-394.

Danielsen, F., Beukema, H., Burgess, N.D., Parish, F., Brühl, C.A., Donald, P.F., Murdiyarso, D., Phalan, B.E.N., Reijnders, L., Struebig, M. \& Fitzherbert, E.B., 2009. Biofuel plantations on forested lands: double jeopardy for biodiversity and climate. Conservation Biology, 23 (2), pp. 348-358. 
Dayan, F.E., Cantrell, C.L. \& Duke, S.O., 2009. Natural products in crop protection. Bioorganic \& medicinal chemistry, 17 (12), pp. 4022-4034.

Dantsis, T., Douma, C., Giourga, C., Loumou, A. \& Polychronaki, E.A., 2010. A methodological approach to assess and compare the sustainability level of agricultural plant production systems. Ecological Indicators, 10 (2), pp. 256-263.

Deininger, K. \& Byerlee, D., 2011. The rise of large farms in land abundant countries: Do they have a future. U.S: The World Bank.

Dale, V.H., Kline, K.L., Kaffka, S.R. \& Langeveld, J.W.A., 2013. A landscape perspective on sustainability of agricultural systems. Landscape Ecology, 28 (6), pp. 1111-1123.

De Olde, E.M., Oudshoorn, F.W., Sørensen, C.A., Bokkers, E.A. \& De Boer, I.J., 2016. Assessing sustainability at farm-level: Lessons learned from a comparison of tools in practice. Ecological Indicators, 66 (1), pp. 391-404.

Diaz-Balteiro, L., Alfranca, O., González-Pachón, J. \& Romero, C., 2016. Ranking of industrial forest plantations in terms of sustainability: A multicriteria approach. Journal of Environmental Management, 180 (1), pp. 123-132.

DeFries, R.S., Fanzo, J., Mondal, P., Remans, R. \& Wood, S.A., 2017. Is voluntary certification of tropical agricultural commodities achieving sustainability goals for small-scale producers? A review of the evidence. Environmental Research Letters, 12 (3), pp. 1-12.

Ewel, J.J., 1986. Designing agricultural ecosystems for the humid tropics. Annual review of ecology and systematics, 17 (1), pp. 245-271.

Edwards, J.H., Wood, C.W., Thurlow, D.L. \& Ruf, M.E., 1992. Tillage and crop rotation effects on fertility status of a Hapludult soil. Soil Science Society of America Journal, 56 (5), pp. 15771582. 
Elkington, J., 1997. Cannibals with Forks: The Triple Bottom Line of 21st Century Business. London: Capstone

Ecobichon, D.J., 2001. Pesticide use in developing countries. Toxicology, 160 (1-3), pp. 27-33.

Essien, J.P., Akpan, E.J., \& Essien, E.P., 2005. Studies on mould growth and biomass production using waste banana peel. Bioresource Technology, 96 (13), pp. 1451-1456.

Elfkih, S., Guidara, I. \& Mtimet, N., 2012. Are Tunisian organic olive growing farms sustainable? An adapted IDEA approach analysis. Spanish Journal of Agricultural Research, 10 (4), 877-889.

Edwards, D.P. \& Laurance, S.G., 2012. Green labelling, sustainability and the expansion of tropical agriculture: critical issues for certification schemes. Biological Conservation, 151 (1), pp. 60-64.

EPA., 2012. A framework for sustainability indicators at EPA. USA: EPA.

FAO., 2001. Global Forest Resources Assessment 2000. Rome: FAO.

Freebairn, D.M. \& King, C.A., 2003. Reflections on collectively working toward sustainability: indicators for indicators!. Australian Journal of Experimental Agriculture, 43 (3), pp. 223-238.

Frank, A.L., McKnight, R., Kirkhorn, S.R., \& Gunderson, P., 2004. Issues of agricultural safety and health. Annu. Rev. Public Health, 25 (1), pp. 225-245.

Foley, J.A., DeFries, R., Asner, G.P., Barford, C., Bonan, G., Carpenter, S.R., Chapin, F.S., Coe, M.T., Daily, G.C., Gibbs, H.K. \& Helkowski, J.H., 2005. Global consequences of land use. Science, 309 (5734), pp. 570-574.

Forrester, D.I., Bauhus, J., Cowie, A.L. \& Vanclay, J.K., 2006. Mixed-species plantations of Eucalyptus with nitrogen-fixing trees: a review. Forest Ecology and Management, 233 (2-3), pp. 211-230. 
Fitzherbert, E.B., Struebig, M.J., Morel, A., Danielsen, F., Brühl, C.A., Donald, P.F. \& Phalan, B., 2008. How will oil palm expansion affect biodiversity?. Trends in ecology \& evolution, 23 (10), pp. 538-545.

Fleskens, L., Duarte, F. \& Eicher, I., 2009. A conceptual framework for the assessment of multiple functions of agro-ecosystems: A case study of Trás-os-Montes olive groves. Journal of Rural Studies, 25 (1), pp. 141-155.

FAO., 2011. Save and Grow: A policymaker's guide to the sustainable intensification of smallholder crop production. Rome: FAO.

FAO, 2013. Sustainability Assessment of Food and Agricultural Systems (SAFA) Guidelines. Rome: FAO.

FAO., 2013. Sustainability Assessment of Food and Agricultural Systems. Rome: FAO.

FAO., 2015. Measuring Sustainability in Cotton Farming Systems: Towards a Guidance Framework. Rome: FAO.

Grant, C.A. \& Bailey, L.D., 1994. The effect of tillage and $\mathrm{KCl}$ addition on $\mathrm{pH}$, conductance, NO3-N, P, K and $\mathrm{Cl}$ distribution in the soil profile. Canadian journal of soil science, 74 (3), pp. 307-314.

Grossman, H.I. \& Iyigun, M.F., 1995. The profitability of colonial investment. Economics \& Politics, 7 (3), pp. 229-241.

Gachene, C.K., Mbuvi, J.P., Jarvis, N.J. \& Linner, H., 1997. Soil erosion effects on soil properties in a highland area of Central Kenya. Soil Science Society of America Journal, 61 (2), pp. 559-564.

Goldemberg, J., Coelho, S.T. \& Guardabassi, P., 2008. The sustainability of ethanol production from sugarcane. Energy policy, 36 (6), pp. 2086-2097.

Gee, G.C., 2008. A multilevel analysis of the relationship between institutional and individual racial discrimination and health status. American journal of public health, 98 (Supplement_1), pp. 48-56. 
Garikipati, S., 2008. Agricultural wage work, seasonal migration and the widening gender gap: Evidence from a semi-arid region of Andhra Pradesh. The European Journal of Development Research, 20 (4), pp. 629-648.

Gómez-Limón, J.A., \& Riesgo, L., 2009. Alternative approaches to the construction of a composite indicator of agricultural sustainability: An application to irrigated agriculture in the Duero basin in Spain. Journal of Environmental Management, 90 (11), pp. 3345-3362.

Gartzia-Bengoetxea, N., González-Arias, A., Kandeler, E. \& Martínez De Arano, I., 2009. Potential indicators of soil quality in temperate forest ecosystems: A case study in the Basque Country. Annals of Forest Science, 66 (3), pp. 1-12

Gasparatos, A., 2010. Embedded value systems in sustainability assessment tools and their implications. Journal of environmental management, 91 (8), pp. 1613-1622.

Gerber, J.F., 2011. Conflicts over industrial tree plantations in the South: Who, how and why?. Global Environmental Change, 21 (1), pp. 165-176.

Giménez, J.C., Bertomeu, M., Diaz-Balteiro, L. \& Romero, C., 2013. Optimal harvest scheduling in Eucalyptus plantations under a sustainability perspective. Forest Ecology and Management, 291 (1), pp. 367-376.

Gaudino, S., Goia, I., Borreani, G., Tabacco, E. \& Sacco, D., 2014. Cropping system intensification grading using an agro-environmental indicator set in northern Italy. Ecological Indicators, 40 (1), pp. 76-89.

Gold, S., Trautrims, A., \& Trodd, Z., 2015. Modern slavery challenges to supply chain management. Supply Chain Management: An International Journal, 20 (5), pp. 485-494.

Gasso, V., Oudshoorn, F.W., de Olde, E. \& Sørensen, C.A., 2015. Generic sustainability assessment themes and the role of context: The case of Danish maize for German biogas. Ecological indicators, 49 (1), pp. 143-153. 
Gentili, R., Ambrosini, R., Montagnani, C., Caronni, S., \& Citterio, S., 2018. Effect of soil pH on the growth, reproductive investment and pollen allergenicity of Ambrosia artemisiifolia L. Frontiers in plant science, 9 (1), pp. 1-12.

Ginesti, G., Caldarelli, A. \& Zampella, A., 2018. Exploring the impact of intellectual capital on company reputation and performance. Journal of Intellectual Capital, 19 (5), pp. 915-934.

Hartemink, A.E., 1998. Soil chemical and physical properties as indicators of sustainable land management under sugar cane in Papua New Guinea. Geoderma, 85 (4), pp. 283-306.

Hess, G.R., Campbell, C.L., Fiscus, D.A., Hellkamp, A.S., McQuaid, B.F., Munster, M.J., Peck, S.L., \& Shafer, S.R., 2000. A conceptual model and indicators for assessing the ecological condition of agricultural lands. Journal of Environmental Quality, 29 (3), pp. 728-737.

Hitt, L.M., Wu, D.J., \& Zhou, X., 2002. Investment in enterprise resource planning: Business impact and productivity measures. Journal of management information systems, 19 (1), pp. 71-98.

Hartley, M.J., 2002. Rationale and methods for conserving biodiversity in plantation forests. Forest Ecology and Management, 155 (1-3), pp. 81-95.

Hueting, R. \& Reijnders, L., 2004. Broad sustainability contra sustainability: the proper construction of sustainability indicators. Ecological economics, 50 (3-4), pp. 249-260.

Hartemink, A.E., 2005. Plantation agriculture in the tropics: Environmental Issues. Outlook on Agriculture, 34 (1), pp. 11-21.

He, J. \& Wang, H.C., 2009. Innovative knowledge assets and economic performance: The asymmetric roles of incentives and monitoring. Academy of Management Journal, 52 (5), pp. 919938. 
Hassan, A. \& Ibrahim, E., 2012. Corporate environmental information disclosure: Factors influencing companies' success in attaining environmental awards. Corporate Social Responsibility and Environmental Management, 19 (1), pp. 32-46.

Halberg, N., 2012. Assessment of the environmental sustainability of organic farming: Definitions, indicators and the major challenges. Canadian Journal of Plant Science, 92 (6), pp. 981-996.

Huang, X., Han, S., Huang, W., \& Liu, X., 2013. Enhancing solar cell efficiency: the search for luminescent materials as spectral converters. Chemical Society Reviews, 42 (1), pp. 173-201.

Hall, R., Scoones, I. \& Tsikata, D., 2017. Plantations, outgrowers and commercial farming in Africa: agricultural commercialisation and implications for agrarian change. Journal of Peasant Studies, 44 (3), pp. 515-537.

IISD., 2009. Linking Farm Level Measurement Systems to Environmental Sustainability Outcomes: Challenges and Ways Forward. Canada: IISD.

Ingram, J., Fry, P. \& Mathieu, A., 2010. Revealing different understandings of soil held by scientists and farmers in the context of soil protection and management. Land Use Policy, 27 (1), pp. 51-60.

Ingram, V., Van Der Werf, E., Kikulwe, E. \& Wesseler, J.H.H., 2016. Evaluating the impacts of plantations and associated forestry operations in Africa - methods and indicators. International Forestry Review, 18 (1), pp. 44-55.

Jones, W. O., 1968. International Encyclopaedia of the Social Sciences. New York: Macmillan and Free Press.

Johnson, J.M.F., Franzluebbers, A.J., Weyers, S.L. \& Reicosky, D.C., 2007. Agricultural opportunities to mitigate greenhouse gas emissions. Environmental pollution, 150 (1), pp. 107124. 
Jayeeta, S., 2009. 'Lazy'natives, coolie labour, and the Assam tea industry. Modern Asian Studies, 43 (6), pp. 1287-1324.

Jackson, L.L. \& Rosenberg, H.R., 2010. Preventing heat-related illness among agricultural workers. Journal of agromedicine, 15 (3), pp. 200-215.

Juhász, L., 2011. Net present value versus internal rate of return. Economics \& Sociology, 4 (1), pp. 46-53.

Jacobi, J., Schneider, M., Bottazzi, P., Pillco, M., Calizaya, P. \& Rist, S., 2015. Agroecosystem resilience and farmers' perceptions of climate change impacts on cocoa farms in Alto Beni, Bolivia. Renewable Agriculture and Food Systems, 30 (2), pp. 170-183.

Jat, M.L., Stirling, C.M., Jat, H.S., Tetarwal, J.P., Jat, R.K., Singh, R., Lopez-Ridaura, S. \& Shirsath, P.B., 2018. Advances in Agronomy. U.S: Academic Press.

Karlson, T. \& Noren, J., 1979. Farm tractor fatalities: the failure of voluntary safety standards. American Journal of Public Health, 69 (2), pp. 146-149.

Klassen, R.D., \& McLaughlin, C.P., 1996. The impact of environmental management on firm performance. Management science, 42 (8), pp. 1199-1214.

Kahlown, M.A. \& Ashraf, M., 2005. Effect of shallow groundwater table on crop water requirements and crop yields. Agricultural Water Management, 76 (1), pp. 24-35.

Kuo, S.F., Ho, S.S. \& Liu, C.W., 2006. Estimation irrigation water requirements with derived crop coefficients for upland and paddy crops in ChiaNan Irrigation Association, Taiwan. Agricultural water management, 82 (3), pp. 433-451.

Kaatz, E., Root, D.S., Bowen, P.A., \& Hill, R.C., 2006. Advancing key outcomes of sustainability building assessment. Building Research and Information, 34 (4), pp. 308-320. 
Kirkegaard, J., Christen, O., Krupinsky, J. \& Layzell, D., 2008. Break crop benefits in temperate wheat production. Field Crops Research, 107 (3), pp. 185-195.

Kolk, A., 2008. Sustainability, accountability and corporate governance: exploring multinationals' reporting practices. Business strategy and the environment, 17 (1), pp. 1-15.

Khasreen, M., Banfill, P.F., \& Menzies, G., 2009. Life-cycle assessment and the environmental impact of buildings: a review. Sustainability, 1 (3), pp. 674-701.

Kothari, U., 2013. Geographies and histories of unfreedom: Indentured labourers and contract workers in Mauritius. The Journal of Development Studies, 49 (8), pp. 1042-1057.

Leitner, K., 1976. The situation of agricultural workers in Kenya. Review of African Political Economy, 3 (6), pp. 34-50.

Lipson, S.M. \& Stotzky, G., 1983. Adsorption of reovirus to clay minerals: effects of cationexchange capacity, cation saturation, and surface area. Applied and environmental microbiology, 46 (3), pp. 673-682.

Lobb, D.A. \& Kachanoski, R.G., 1999. Modelling tillage erosion in the topographically complex landscapes of southwestern Ontario, Canada. Soil and Tillage Research, 51 (3-4), pp. 261-277.

Lim, J.N.W. \& Douglas, I., 2000. Land management policy and practice in a steepland agricultural area: a Malaysian example. Land Degradation \& Development, 11 (1), pp. 51-61.

Lipiec, J. \& Hatano, R., 2003. Quantification of compaction effects on soil physical properties and crop growth. Geoderma, 116 (1-2), pp. 107-136.

Linton, A., 2005. Partnering for sustainability: business-NGO alliances in the coffee industry. Development in Practice, 15 (3-4), pp. 600-614. 
Labuschagne, C., Brent, A.C. \& Van Erck, R.P., 2005. Assessing the sustainability performances of industries. Journal of cleaner production, 13 (4), pp. 373-385.

Li, H., Aide, T.M., Ma, Y., Liu, W. \& Cao, M., 2006. Demand for rubber is causing the loss of high diversity rain forest in SW China. In Plant Conservation and Biodiversity (pp. 157-171). Springer, Dordrecht.

Lobb, D.A., Huffman, E. \& Reicosky, D.C., 2007. Importance of information on tillage practices in the modelling of environmental processes and in the use of environmental indicators. Journal of Environmental Management, 82 (3), pp. 377-387.

Lichtfouse, E., Navarrete, M., Debaeke, P., Souchère, V., Alberola, C., \& Ménassieu, J., 2009. Agronomy for sustainable agriculture: A Review. Agronomy for Sustainable Development, 29 (1), pp. 1-7.

Liberati, A., Altman, D.G., Tetzlaff, J., Mulrow, C., Gøtzsche, P.C., Ioannidis, J.P., Clarke, M., Devereaux, P.J., Kleijnen, J., \& Moher, D., 2009. The PRISMA statement for reporting systematic reviews and meta-analyses of studies that evaluate health care interventions: explanation and elaboration. PLoS medicine, 6 (7), pp. 1-28.

Lecours, N., Almeida, G.E., Abdallah, J.M., \& Novotny, T.E., 2012. Environmental health impacts of tobacco farming: a review of the literature. Tobacco control, 21 (2), pp. 191-196.

Lee, B.Y., Bacon, K.M., Bottazzi, M.E. \& Hotez, P.J., 2013. Global economic burden of Chagas disease: a computational simulation model. The Lancet infectious diseases, 13 (4), pp. 342-348.

Ludin, N.A., Bakri, M.A.M., Kamaruddin, N., Sopian, K., Deraman, M.S., Hamid, N.H., Asim, N. \& Othman, M.Y., 2014. Malaysian oil palm plantation sector: Exploiting renewable energy toward sustainability production. Journal of cleaner production, 65 (1), pp. 9-15. 
Li, Y., Härdtle, W., Bruelheide, H., Nadrowski, K., Scholten, T., von Wehrden, H. \& von Oheimb, G., 2014. Site and neighborhood effects on growth of tree saplings in subtropical plantations (China). Forest Ecology and Management, 327 (1), pp. 118-127.

Labrière, N., Locatelli, B., Laumonier, Y., Freycon, V., \& Bernoux, M., 2015. Soil erosion in the humid tropics: A systematic quantitative review. Agriculture, Ecosystems \& Environment, 203 (1), pp. 127-139.

Leventon, J., Fleskens, L., Claringbould, H., Schwilch, G., \& Hessel, R., 2016. An applied methodology for stakeholder identification in transdisciplinary research. Sustainability Science, $11(5)$, pp. 763-775.

Latruffe, L., Diazabakana, A., Bockstaller, C., Desjeux, Y., \& Finn, J., 2016. Measurement of sustainability in agriculture: A review of indicators. Studies in Agricultural Economics, 118 (3), pp. 123-130.

Lynch, J., Donnellan, T., Finn, J.A., Dillon, E. \& Ryan, M., 2019. Potential development of Irish agricultural sustainability indicators for current and future policy evaluation needs. Journal of environmental management, 230 (1), pp. 434-445.

Li, T., Hua, F., Dan, S., Zhong, Y., Levey, C. \& Song, Y., 2020. Reporting quality of systematic review abstracts in operative dentistry: An assessment using the PRISMA for abstracts guidelines. Journal of Dentistry, 102 (2020), pp. 1-8.

McCurdy, S.A. \& Carroll, D.J., 2000. Agricultural injury. American journal of industrial medicine, 38 (4), pp. 463-480.

Meppem, T., 2000. The discursive community: Evolving institutional structures for planning Sustainability. Ecological Economics, 34 (1), pp. 47-61

Morash, E.A., 2001. Supply chain strategies, capabilities, and performance. Transportation journal, 2001 (1), pp. 37-54.

Moretti, E. \& Perloff, J.M., 2002. Efficiency wages, deferred payments, and direct incentives in agriculture. American Journal of Agricultural Economics, 84 (4), pp. 1144-1155. 
Martius, C., Tiessen, H. \& Vlek, P., 2002. Managing Organic Matter in Tropical Soils: Scope and Limitations. Germany: Springer Science \& Business Media.

McMahon, J., 2002. Case studies of violations of workers' freedom of association: migrant agricultural workers: human rights watch. International Journal of Health Services, 32 (3), pp. 443-465.

Marras, I., 2003. UNEP: The power of choice. Journal of Cleaner Production, 8 (11), pp. 927929.

Mannan, M.A., \& Ganapathy, C., 2004. Concrete from an agricultural waste-oil palm shell (OPS). Building and environment, 39 (4), pp. 441-448.

Montgomery, D.R., 2007. Soil erosion and agricultural sustainability. Proceedings of the National Academy of Sciences, 104 (33), pp. 13268-13272.

Marlenga, B., Berg, R.L., Linneman, J.G., Brison, R.J. \& Pickett, W., 2007. Changing the child labor laws for agriculture: impact on injury. American journal of public health, 97 (2), pp. 276282.

Mingorría, S., Gamboa, G., Martín-López, B. \& Corbera, E., 2014. The oil palm boom: socioeconomic implications for Q'eqchi'households in the Polochic valley, Guatemala. Environment, development and sustainability, 16 (4), pp. 841-871.

Munyanduki, P., Chirwa, P.W. \& Babalola, F.D., 2016. A case study assessment of socioeconomic sustainability and alternative management regimes for state forest plantations in Limpopo Province, South Africa. Agroforestry Systems, 90 (4), pp. 675-689.

Mahon, N., Crute, I., Simmons, E., \& Islam, M.M., 2017. Sustainable intensification “oxymoron" or "third-way"? A systematic review. Ecological Indicators, 74 (2017), pp. 73-97.

Martin-Guay, M.O., Paquette, A., Dupras, J. \& Rivest, D., 2018. The new green revolution: sustainable intensification of agriculture by intercropping. Science of the Total Environment, 615 (1), pp. 767-772.

Mingorría, S., 2018. Violence and visibility in oil palm and sugarcane conflicts: the case of Polochic Valley, Guatemala. The Journal of Peasant Studies, 45 (7), pp. 1314-1340. 
Nambiar, K.K.M., Gupta, A.P., Fu, Q., \& Li, S., 2001. Biophysical, chemical and socio-economic indicators for assessing agricultural sustainability in the Chinese coastal zone. Agriculture, Ecosystems and Environment, 87 (2), pp. 209-214

Nonhebel, S., 2005. Renewable energy and food supply: will there be enough land?. Renewable and sustainable energy reviews, 9 (2), pp. 191-201.

Nichols, J.D., Bristow, M. \& Vanclay, J.K., 2006. Mixed-species plantations: prospects and challenges. Forest Ecology and Management, 233 (2-3), pp. 383-390.

Naveen, R., Swaroop, N., Agrawal, S. \& Tirkey, A.K., 2013. Profile of occupational accidents reporting to a rural plantation hospital: A record review. International Journal of Occupational Safety and Health, 3 (2), pp. 18-20.

Ning, C.C., Gao, P.D., Wang, B.Q., Lin, W.P., Jiang, N.H. \& Cai, K.Z., 2017. Impacts of chemical fertilizer reduction and organic amendments supplementation on soil nutrient, enzyme activity and heavy metal content. Journal of integrative agriculture, 16 (8), pp. 1819-1831.

Okafor, F.O., 1991. An investigation on the use of superplasticizer in palm kernel shell aggregate concrete. Cement and Concrete research, 21 (4), pp. 551-557.

Orhangazi, Ö., 2008. Financialization and capital accumulation in the non-financial corporate sector: A theoretical and empirical investigation on the US economy: 1973-2003. Cambridge Journal of Economics, 32 (6), pp. 863-886.

Obidzinski, K., Andriani, R., Komarudin, H. \& Andrianto, A., 2012. Environmental and social impacts of oil palm plantations and their implications for biofuel production in Indonesia. Ecology and Society, 17 (1), pp. 1-19

Oliveira Pasiani, J., Torres, P., Roniery Silva, J., Diniz, B.Z. \& Caldas, E., 2012. Knowledge, attitudes, practices and biomonitoring of farmers and residents exposed to pesticides in Brazil. International journal of environmental research and public health, 9 (9), pp. 3051-3068.

Osman, K.T. 2013. Soils. Dordrecht: Springer. 
Ostfeld, R., Howarth, D., Reiner, D. \& Krasny, P., 2019. Peeling back the label-exploring sustainable palm oil ecolabelling and consumption in the United Kingdom. Environmental Research Letters, 14 (1), pp. 1-10.

Pease, J.J., 1985. Confectionery fats from palm oil and lauric oil. Journal of the American Oil Chemists' Society, 62 (2), pp. 426-430.

Parris, T.M. \& Kates, R.W., 2003. Characterizing and measuring sustainable development. Annual Review of environment and resources, 28 (1), pp. 559-586.

Petit, B. \& Montagnini, F., 2004. Growth equations and rotation ages of ten native tree species in mixed and pure plantations in the humid neotropics. Forest Ecology and Management, 199 (2-3), pp. 243-257.

Pineda, E., Moreno, C., Escobar, F., \& Halffter, G., 2005. Frog, Bat, and Dung Beetle Diversity in the Cloud Forest and Coffee Agroecosystems of Veracruz, Mexico. Conservation Biology, 19 (2), pp. 400-410.

Posthumus, H., Hewett, C.J.M., Morris, J. \& Quinn, P.F., 2008. Agricultural land use and flood risk management: engaging with stakeholders in North Yorkshire. Agricultural Water Management, 95 (7), pp. 787-798.

Pretty, J., Smith, G., Goulding, K.W.T., Groves, S.J., Henderson, I., Hine, R.E., King, V., Van Oostrum, J., Pendlington, D.J., Vis, J.K., \& Walter, C., 2008. Multi-year assessment of Unilever's progress towards agricultural sustainability II: Outcomes for peas (UK), spinach (Germany, Italy), tomatoes (Australia, Brazil, Greece, USA), tea (Kenya, Tanzania, India) and oil palm (Ghana). International Journal of Agricultural Sustainability, 6 (1), pp. 63-88.

Prueksakorn, K., Gheewala, S.H., Malakul, P. \& Bonnet, S., 2010. Energy analysis of Jatropha plantation systems for biodiesel production in Thailand. Energy for Sustainable Development, 14 (1), pp. 1-5.

Pretty, J., Sutherland, W.J., Ashby, J., Auburn, J., Baulcombe, D., Bell, M., Bentley, J., Bickersteth, S., Brown, K., Burke, J. \& Campbell, H., 2010. The top 100 questions of importance to the future of global agriculture. International journal of agricultural sustainability, 8 (4), pp. 219-236. 
Partzsch, L., 2011. The legitimacy of biofuel certification. Agriculture and Human Values, 28 (3), pp. 413-425.

Padam, B.S., Tin, H.S., Chye, F.Y., \& Abdullah, M.I., 2014. Banana by-products: an underutilized renewable food biomass with great potential. Journal of food science and technology, 51 (12), pp. 3527-3545.

Papadopoulos, A., Bird, N.R.A., Whitmore, A.P., \& Mooney, S.J., 2014. Does organic management lead to enhanced soil physical quality? Geoderma, 213 (1), pp. 435-443.

Porio, E., 2015. Sustainable development goals and quality of life targets: Insights from Metro Manila. Current Sociology, 63 (2), pp. 244-260.

Patra, S., Mishra, P., Mahapatra, S.C. \& Mithun, S.K., 2016. Modelling impacts of chemical fertilizer on agricultural production: a case study on Hooghly district, West Bengal, India. Modeling Earth Systems and Environment, 2 (4), pp. 1-11.

Prasara-A, J., \& Gheewala, S.H., 2016. Sustainability of sugarcane cultivation: case study of selected sites in north-eastern Thailand. Journal of Cleaner Production, 134 (Part B), pp. 613-622.

Pajula, T., Behm, K., Vatanen, S., \& Saarivuori, E., 2017. Managing the Life Cycle to Reduce Environmental Impacts. Switzerland: Springer.

Partzsch, L., Zander, M. \& Robinson, H., 2019. Cotton certification in Sub-Saharan Africa: Promotion of environmental sustainability or greenwashing. Global Environmental Change, 57 (1), pp. 1-10.

Quelch, J.A., 1987. Marketing the premium product. Business horizons, 30 (3), pp. 38-45.

Quétier, F. \& Lavorel, S., 2011. Assessing ecological equivalence in biodiversity offset schemes: key issues and solutions. Biological conservation, 144 (12), pp. 2991-2999.

Richardson, B., Skinner, M.F. \& West, G., 1999. The role of forest productivity in defining the sustainability of plantation forests in New Zealand. Forest Ecology and Management, 122 (1-2), pp. 125-137.

Rainforest Alliance., 2005. Sustainable Agriculture Standard with Indicators: Sustainable Agriculture Network. Costa Rica: Rainforest Alliance. 
Roome, N., 2005. Teaching sustainability in a global MBA: Insights from the OneMBA. Business Strategy and the Environment, 14 (3), pp. 160-171.

Rai, A., Patnayakuni, R. \& Seth, N., 2006. Firm performance impacts of digitally enabled supply chain integration capabilities. MIS quarterly, 2006 (1), pp. 225-246.

Resch, G., Held, A., Faber, T., Panzer, C., Toro, F., \& Haas, R., 2008. Potentials and prospects for renewable energies at global scale. Energy policy, 36 (11), pp. 4048-4056.

Rossel, R.V., Adamchuk, V.I., Sudduth, K.A., McKenzie, N.J. \& Lobsey, C., 2011. Advances in agronomy. U.S: Academic Press.

Romm, J., 2011. Desertification: The next dust bowl. Nature, 478 (7370), pp. 450-451.

Ray, D.K., Ramankutty, N., Mueller, N.D., West, P.C., \& Foley, J.A., 2012. Recent patterns of crop yield growth and stagnation. Nature communications, 3 (1), pp. 1-7.

Reddy, K.S., Pankaj, P.K., Reddy, N.N. \& Raju, N.S., 2016. Participatory Rural Appraisal in Drylands: A Holistic Approach for Getting Insight into an Agro-Ecosystem Analysis. Journal of Rural Development, 35 (4), pp. 555-580.

Rasmussen, L.V., Bierbaum, R., Oldekop, J.A. \& Agrawal, A., 2017. Bridging the practitionerresearcher divide: Indicators to track environmental, economic, and sociocultural sustainability of agricultural commodity production. Global Environmental Change, 42 (1), pp. 33-46.

Rodrigues, G.S., Martins, C.R. \& de Barros, I., 2018. Sustainability assessment of ecological intensification practices in coconut production. Agricultural Systems, 165 (1), pp. 71-84.

Ramos, A.K., 2018. Child labour in global tobacco production: A human rights approach to an enduring dilemma. Health and human rights, 20 (2), pp. 235-248

Sumner, M.E., 1994. Measurement of soil pH: problems and solutions. Communications in Soil Science and Plant Analysis, 25 (7-8), pp. 859-879.

Sparks, D.L., Page, A.L., Helmke, P.A. \& Loeppert, R.H., 1996. Methods of soil analysis (Part 3): Chemical methods. U.S.A: John Wiley \& Sons.

Shepherd, A., \& Bowler, C., 1997. Beyond the requirements: Improving public participation in EIA. Journal of Environmental Planning and management, 40 (6), pp. 725-738. 
Saiyed, H.N. \& Tiwari, R.R., 2004. Occupational health research in India. Industrial health, 42 (2), pp. 141-148.

Shah, M.P., Reddy, G.V., Banerjee, R., Babu, P.R., \& Kothari, I.L., 2005. Microbial degradation of banana waste under solid state bioprocessing using two lignocellulolytic fungi. Process Biochemistry, 40 (1), pp. 445-451.

Stroosnijder, L., 2005. Measurement of erosion: is it possible?. Catena, 64 ( 2-3), pp. 162-173.

Strijker, D., 2005. Marginal lands in Europe — causes of decline. Basic and Applied Ecology, 6 (2), pp. 99-106.

Shreck, A., Getz, C. \& Feenstra, G., 2006. Social sustainability, farm labor, and organic agriculture: Findings from an exploratory analysis. Agriculture and Human Values, 23 (4), pp.439449.

Scoones, I., 2007. Sustainability. Development in Practice, 17 (4-5), pp. 589-596.

Smith, G.F., Gittings, T., Wilson, M., French, L., Oxbrough, A., O'Donoghue, S., O'Halloran, J., Kelly, D.L., Mitchell, F.J.G., Kelly, T., Iremonger, S., McKee, A.-. \& Giller, P., 2008. Identifying practical indicators of biodiversity for stand-level management of plantation forests. Biodiversity and Conservation, 17 (5), pp. 991-1015.

Singh, G., 2009. Salinity-related desertification and management strategies: Indian experience. Land Degradation \& Development, 20 (4), pp. 367-385.

Sydorovych, O., Raczkowski, C.W., Wossink, A., Mueller, J.P., Creamer, N.G., Hu, S., Bell, M. \& Tu, C., 2009. A technique for assessing environmental impact risks of agricultural systems. Renewable Agriculture and Food Systems, 24 (3), pp. 234-243.

Silici, L., Ndabe, P., Friedrich, T. \& Kassam, A., 2011. Harnessing sustainability, resilience and productivity through conservation agriculture: the case of likoti in Lesotho. International journal of agricultural sustainability, 9 (1), pp. 137-144.

Sheth, J.N., Sethia, N.K. \& Srinivas, S., 2011. Mindful consumption: a customer-centric approach to sustainability. Journal of the Academy of Marketing Science, 39 (1), pp. 21-39. 
Shafigh, P., Jumaat, M.Z., \& Mahmud, H., 2011. Oil palm shell as a lightweight aggregate for production high strength lightweight concrete. Construction and Building Materials, 25 (4), pp. 1848-1853.

Savci, S., 2012. Investigation of effect of chemical fertilizers on environment. Apcbee Procedia, 1 (1), pp. 287-292.

Seddaiu, G., Porcu, G., Ledda, L., Roggero, P.P., Agnelli, A. \& Corti, G., 2013. Soil organic matter content and composition as influenced by soil management in a semi-arid Mediterranean agrosilvo-pastoral system. Agriculture, Ecosystems \& Environment, 167 (1), pp. 1-11.

Schnackenberg, A.K. \& Tomlinson, E.C., 2016. Organizational transparency: A new perspective on managing trust in organization-stakeholder relationships. Journal of Management, 42 (7), pp. 1784-1810.

Schader, C., Baumgart, L., Landert, J., Muller, A., Ssebunya, B., Blockeel, J., Weisshaidinger, R., Petrasek, R., Mészáros, D., Padel, S., \& Gerrard, C., 2016. Using the sustainability monitoring and assessment routine (smart) for the systematic analysis of trade-offs and synergies between sustainability dimensions and themes at farm level. Sustainability, 8 (3), p. 274.

Singh, S., \& Benbi, D.K., 2016. Punjab-Soil Health and Green Revolution: A Quantitative Analysis of Major Soil Parameters. Journal of Crop Improvement, 30 (3), pp. 323-340.

Santoso, H.B., \& Delima, R., 2017. Stakeholder Definition for Indonesian Integrated Agriculture Information System (IAIS). Materials Science and Engineering, 185 (2017), pp. 1-7.

Sun, Y., Cao, F., Wei, X., Welham, C., Chen, L., Pelz, D., Yang, Q. \& Liu, H., 2017. An Ecologically Based System for Sustainable Agroforestry in Sub-Tropical and Tropical Forests. Forests, 8 (4), pp. 1-18.

Schweier, J., Spinelli, R., Magagnotti, N., Wolfslehner, B. \& Lexer, M., 2018. Sustainability Assessment of Alternative Thinning Operations in Mediterranean Softwood Plantations. Forests, 9 (7), pp. 1-17.

Safitri, L., Hermantoro, H., Purboseno, S., Kautsar, V., Saptomo, S.K. \& Kurniawan, A., 2018. Water footprint and crop water usage of oil palm (Eleasis guineensis) in Central Kalimantan: 
Environmental sustainability indicators for different crop age and soil conditions. Water (Switzerland), 11 (1), p. 35

Santika, T., Wilson, K.A., Budiharta, S., Law, E.A., Poh, T.M., Ancrenaz, M., Struebig, M.J. \& Meijaard, E., 2019. Does oil palm agriculture help alleviate poverty? A multidimensional counterfactual assessment of oil palm development in Indonesia. World Development, 120 (1), pp. 105-117.

The World Bank., 1998. Performance Indicators for Sustainable Agriculture. U.S: The World Bank.

Tellarini, V., \& Caporali, F., 2000. An input/output methodology to evaluate farms as sustainable agroecosystems: An application of indicators to farms in central Italy. Agriculture, Ecosystems and Environment, 77 (1-2), pp. 111-123.

Tilman, D., Cassman, K.G., Matson, P.A., Naylor, R. \& Polasky, S., 2002. Agricultural sustainability and intensive production practices. Nature, 418 (6898), pp. 671-677.

Tilman, D., Balzer, C., Hill, J. \& Befort, B.L., 2011. Global food demand and the sustainable intensification of agriculture. Proceedings of the National Academy of Sciences, 108 (50), pp. 20260-20264.

Thierfelder, C., Cheesman, S. \& Rusinamhodzi, L., 2012. A comparative analysis of conservation agriculture systems: Benefits and challenges of rotations and intercropping in Zimbabwe. Field crops research, 137 (1), pp. 237-250.

Thivierge, M., Parent, D., Belanger, V., Angers, D.A., Allard, G., Pellerin, D. \& Vanasse, A., 2014. Environmental sustainability indicators for cash-crop farms in Quebec, Canada: A participatory approach. Ecological Indicators, 45 (1), pp. 677-686.

Tsikata, D. \& Yaro, J.A., 2014. When a good business model is not enough: Land transactions and gendered livelihood prospects in rural Ghana. Feminist economics, 20 (1), pp. 202-226.

Testa, R., Foderà, M., Di Trapani, A.M., Tudisca, S. \& Sgroi, F., 2015. Choice between alternative investments in agriculture: The role of organic farming to avoid the abandonment of rural areas. Ecological engineering, 83 (1), pp. 227-232. 
UN., 2007. Indicators of sustainable development: guidelines and methodologies. New York: UN.

Utomo, B., Prawoto, A.A., Bonnet, S., Bangviwat, A. \& Gheewala, S.H., 2016. Environmental performance of cocoa production from monoculture and agroforestry systems in Indonesia. Journal of Cleaner Production, 134 (Part B), pp. 583-591.

Villarejo, D., 2003. The health of US hired farm workers. Annual review of public health, 24 (1), pp. 175-193.

Van Cauwenbergh, N., Biala, K., Bielders, C., Brouckaert, V., Franchois, L., Garcia Cidad, V., Hermy, M., Mathijs, E., Muys, B., Reijnders, J., Sauvenier, X., Valckx, J., Vanclooster, M., Van der Veken, B., Wauters, E. \& Peeters, A., 2007. SAFE—A hierarchical framework for assessing the sustainability of agricultural systems. Agriculture, Ecosystems \& Environment, 120 (2), pp. 229-242.

Villarejo, D., McCurdy, S.A., Bade, B., Samuels, S., Lighthall, D. \& Williams III, D., 2010. The health of California's immigrant hired farmworkers. American journal of industrial medicine, 53 (4), pp. 387-397.

Van Eijck, J., Romijn, H., Smeets, E., Bailis, R., Rooijakkers, M., Hooijkaas, N., Verweij, P. \& Faaij, A., 2014. Comparative analysis of key socio-economic and environmental impacts of smallholder and plantation based jatropha biofuel production systems in Tanzania. Biomass and Bioenergy, 61 (1), pp. 25-45.

Vanhove, W., Vanhoudt, N. \& Van Damme, P., 2016. Effect of shade tree planting and soil management on rehabilitation success of a 22-year-old degraded cocoa (Theobroma cacao L.) plantation. Agriculture, Ecosystems and Environment, 219 (1), pp. 14-25.

WCED., 1987. Our Common Future. Oxford: Oxford University Press.

Williams, R., \& Walcott, J., 1998. Environmental benchmarks for agriculture? Clarifying the framework in a federal system - Australia. Land use Policy, 15 (2), pp. 149-163.

Wilson, C. \& Tisdell, C., 2001. Why farmers continue to use pesticides despite environmental, health and sustainability costs. Ecological economics, 39 (3), pp. 449-462. 
Williams, K., Nettle, R. \& Petheram, R.J., 2003. Public response to plantation forestry on farms in south-western Victoria. Australian Forestry, 66 (2), pp. 93-99.

Wicke, B., Sikkema, R., Dornburg, V. \& Faaij, A., 2011. Exploring land use changes and the role of palm oil production in Indonesia and Malaysia. Land use Policy, 28 (1), pp. 193-206.

Waas, T., Hugé, J., Block, T., Wright, T., Benitez-Capistros, F. \& Verbruggen, A., 2014. Sustainability assessment and indicators: Tools in a decision-making strategy for sustainable development. Sustainability, 6 (9), pp. 5512-5534.

Wu, W., Liu, Y., Zhang, Q. \& Yu, B., 2019. How innovative knowledge assets and firm transparency affect sustainability-friendly practices. Journal of Cleaner Production, 229 (1), pp. $32-43$.

Xu, Q., Jiang, P. \& Xu, Z., 2008. Soil microbial functional diversity under intensively managed bamboo plantations in southern China. Journal of Soils and Sediments, 8 (3), pp. pp. 177-183.

Xavier, A., Freitas, M.D.B.C., Fragoso, R. \& do Socorro Rosário, M., 2018. A regional composite indicator for analysing agricultural sustainability in Portugal: A goal programming approach. Ecological Indicators, 89 (1), pp. 84-100.

Yli-Viikari, A., 1999. Indicators for sustainable agriculture - A theoretical framework for classifying and assessing indicators. Agricultural and Food Science in Finland, 8 (3), pp. 265-283.

Yi, Z.F., Cannon, C.H., Chen, J., Ye, C.X. \& Swetnam, R.D., 2014. Developing indicators of economic value and biodiversity loss for rubber plantations in Xishuangbanna, southwest China: A case study from Menglun township. Ecological Indicators, 36 (1), pp. 788-797.

Yaro, J.A., Teye, J.K. \& Torvikey, G.D., 2017. Agricultural commercialisation models, agrarian dynamics and local development in Ghana. The Journal of Peasant Studies, 44 (3), pp. 538-554.

Zapfack, L., Engwald, S., Sonke, B., Achoundong, G. \& Madong, B.A., 2002. The impact of land conversion on plant biodiversity in the forest zone of Cameroon. Biodiversity \& Conservation, 11 (11), pp. 2047-2061. 
Zhao, L., Xia, J., Xu, C.Y., Wang, Z., Sobkowiak, L. \& Long, C., 2013. Evapotranspiration estimation methods in hydrological models. Journal of Geographical Sciences, 23 (2), pp. 359369.

Zhang, Y., Ni, J., Yang, J., Zhang, T. \& Xie, D., 2017. Citrus stand ages regulate the fraction alteration of soil organic carbon under a citrus/Stropharua rugodo-annulata intercropping system in the Three Gorges Reservoir area, China. Environmental Science and Pollution Research, 24 (22), pp. 18363-18371.

\section{Appendix A: The list of sampled articles analyzed in this systematic review}

1. Bonilla, S.H., Guarnetti, R.L., Almeida, C.M.V.B. \& Giannetti, B.F., 2010. Sustainability assessment of a giant bamboo plantation in Brazil: exploring the influence of labour, time and space. Journal of Cleaner Production, 18 (1), pp. 83-91.

2. Bellamy, A.S., Svensson, O., van den Brink, P.J. \& Tedengren, M., 2016. What is in a label? Rainforest-Alliance certified banana production versus non-certified conventional banana production. Global Ecology and Conservation, 7 (1), pp. 39-48.

3. Coote, L., Dietzsch, A.C., Wilson, M.W., Graham, C.T., Fuller, L., Walsh, A.T., Irwin, S., Kelly, D.L., Mitchell, F.J.G., Kelly, T.C. \& O'Halloran, J., 2013. Testing indicators of biodiversity for plantation forests. Ecological Indicators, 32 (1), pp. 107-115.

4. COSA., 2013. The COSA Measuring Sustainability Report: Coffee and Cocoa in 12 Countries. Philadelphia: The Committee on Sustainability Assessment (COSA).

5. Chopin, P., Doré, T., Guindé, L. \& Blazy, J.-., 2015. MOSAICA: A multi-scale bioeconomic model for the design and ex ante assessment of cropping system mosaics. Agricultural Systems, 140 (1), pp. 26-39

6. Chopin, P., Tirolien, J. \& Blazy, J., 2016. Ex-ante sustainability assessment of cleaner banana production systems. Journal of Cleaner Production, 139 (1), pp. 15-24.

7. Dantsis, T., Douma, C., Giourga, C., Loumou, A. \& Polychronaki, E.A., 2010. A methodological approach to assess and compare the sustainability level of agricultural plant production systems. Ecological Indicators, 10 (2), pp. 256-263. 
8. Diaz-Balteiro, L., Alfranca, O., González-Pachón, J. \& Romero, C., 2016. Ranking of industrial forest plantations in terms of sustainability: A multicriteria approach. Journal of Environmental Management, 180 (1), pp. 123-132.

9. Elfkih, S., Guidara, I. \& Mtimet, N., 2012. Are Tunisian organic olive growing farms sustainable? An adapted IDEA approach analysis. Spanish Journal of Agricultural Research, 10 (4), pp. 877-889.

10. Fleskens, L., Duarte, F. \& Eicher, I., 2009. A conceptual framework for the assessment of multiple functions of agro-ecosystems: A case study of Tras-os-Montes olive groves. Journal of Rural Studies, 25 (1), pp. 141-155.

11. FAO., 2013. Sustainability Assessment of Food and Agricultural Systems. Rome: Food and Agriculture Organization of the United Nations (FAO).

12. FAO., 2015. Measuring Sustainability in Cotton Farming Systems: Towards a Guidance Framework. Rome: Food and Agriculture Organization of the United Nations (FAO).

13. Gómez-Limón, J.A., \& Riesgo, L., 2009. Alternative approaches to the construction of a composite indicator of agricultural sustainability: An application to irrigated agriculture in the Duero basin in Spain. Journal of Environmental Management, 90 (11), pp. 3345-3362.

14. Gartzia-Bengoetxea, N., González-Arias, A., Kandeler, E. \& Martínez De Arano, I., 2009. Potential indicators of soil quality in temperate forest ecosystems: A case study in the Basque Country. Annals of Forest Science, 66 (3), pp. 1-12

15. Giménez, J.C., Bertomeu, M., Diaz-Balteiro, L. \& Romero, C., 2013. Optimal harvest scheduling in Eucalyptus plantations under a sustainability perspective. Forest Ecology and Management, 291 (1), pp. 367-376.

16. Gaudino, S., Goia, I., Borreani, G., Tabacco, E. \& Sacco, D., 2014. Cropping system intensification grading using an agro-environmental indicator set in northern Italy. Ecological Indicators, 40 (1), pp. 76-89.

17. Hartemink, A.E., 1998. Soil chemical and physical properties as indicators of sustainable land management under sugar cane in Papua New Guinea. Geoderma, 85 (4), pp. 283-306. 
18. Ingram, V., Van Der Werf, E., Kikulwe, E. \& Wesseler, J.H.H., 2016. Evaluating the Impacts of Plantations and Associated Forestry Operations in Africa-Methods and Indicators. International Forestry Review, 18 (1), pp. 44-55.

19. Jacobi, J., Schneider, M., Bottazzi, P., Pillco, M., Calizaya, P. \& Rist, S., 2015. Agroecosystem resilience and farmers' perceptions of climate change impacts on cocoa farms in Alto Beni, Bolivia. Renewable Agriculture and Food Systems, 30 (2), pp. 170183.

20. Munyanduki, P., Chirwa, P.W. \& Babalola, F.D., 2016. A case study assessment of socioeconomic sustainability and alternative management regimes for state forest plantations in Limpopo Province, South Africa. Agroforestry Systems, 90 (4), pp. 675-689.

21. Pineda, E., Moreno, C., Escobar, F., \& Halffter, G., 2005. Frog, Bat, and Dung Beetle Diversity in the Cloud Forest and Coffee Agroecosystems of Veracruz, Mexico. Conservation Biology, 19 (2), pp. 400-410

22. Pretty, J., Smith, G., Goulding, K.W.T., Groves, S.J., Henderson, I., Hine, R.E., King, V., Van Oostrum, J., Pendlington, D.J., Vis, J.K. \& Walter, C., 2008. Multi-year assessment of Unilever's progress towards agricultural sustainability II: Outcomes for peas (UK), spinach (Germany, Italy), tomatoes (Australia, Brazil, Greece, USA), tea (Kenya, Tanzania, India) and oil palm (Ghana). International Journal of Agricultural Sustainability, 6(1), pp. 63-88.

23. Prasara-A, J., \& Gheewala, S.H., 2016. Sustainability of sugarcane cultivation: case study of selected sites in north-eastern Thailand. Journal of Cleaner Production, 134 (Part B), pp. 613-622.

24. Rainforest Alliance., 2005. Sustainable Agriculture Standard with Indicators: Sustainable Agriculture Network. Costa Rica: Rainforest Alliance.

25. Rodrigues, G.S., Martins, C.R. \& de Barros, I., 2018. Sustainability assessment of ecological intensification practices in coconut production. Agricultural Systems, 165 (1), pp. 71-84. 
26. Smith, G.F., Gittings, T., Wilson, M., French, L., Oxbrough, A., O'Donoghue, S., O'Halloran, J., Kelly, D.L., Mitchell, F.J.G., Kelly, T., Iremonger, S., McKee, A.-. \& Giller, P., 2008. Identifying practical indicators of biodiversity for stand-level management of plantation forests. Biodiversity and Conservation, 17 (5), pp. 991-1015.

27. Sydorovych, O., Raczkowski, C.W., Wossink, A., Mueller, J.P., Creamer, N.G., Hu, S., Bell, M. \& Tu, C., 2009. A technique for assessing environmental impact risks of agricultural systems. Renewable Agriculture and Food Systems, 24 (3), pp. 234-243.

28. Singh, S., \& Benbi, D.K., 2016. Punjab-Soil Health and Green Revolution: A Quantitative Analysis of Major Soil Parameters. Journal of Crop Improvement, 30 (3), pp. 323-340.

29. Sun, Y., Cao, F., Wei, X., Welham, C., Chen, L., Pelz, D.R., Yang, Q. \& Liu, H., 2017. An ecologically based system for sustainable agroforestry in sub-tropical and tropical forests. Forests, 8 (4), pp. 1-18.

30. Safitri, L., Hermantoro, H., Purboseno, S., Kautsar, V., Saptomo, S.K. \& Kurniawan, A., 2018. Water footprint and crop water usage of oil palm (Eleasis guineensis) in Central Kalimantan: Environmental sustainability indicators for different crop age and soil conditions. Water (Switzerland), 11 (1), pp. 1-16.

31. Schweier, J., Spinelli, R., Magagnotti, N., Wolfslehner, B. \& Lexer, M.J., 2018. Sustainability assessment of alternative thinning operations in mediterranean softwood plantations. Forests, 9 (7), pp. 1-17.

32. Tellarini, V., \& Caporali, F., 2000. An input/output methodology to evaluate farms as sustainable agroecosystems: An application of indicators to farms in central Italy. Agriculture, Ecosystems and Environment, 77 (1-2), pp. 111-123.

33. Thivierge, M., Parent, D., Belanger, V., Angers, D.A., Allard, G., Pellerin, D. \& Vanasse, A., 2014. Environmental sustainability indicators for cash-crop farms in Quebec, Canada: A participatory approach. Ecological Indicators, 45 (1), pp. 677-686.

34. Testa, R., Foderà, M., Di Trapani, A.M., Tudisca, S. \& Sgroi, F., 2015. Choice between alternative investments in agriculture: The role of organic farming to avoid the abandonment of rural areas. Ecological Engineering, 83 (1), pp. 227-232. 
35. Utomo, B., Prawoto, A.A., Bonnet, S., Bangviwat, A. \& Gheewala, S.H., 2016. Environmental performance of cocoa production from monoculture and agroforestry systems in Indonesia. Journal of Cleaner Production, 134 (Part B), pp. 583-591.

36. Van Eijck, J., Romijn, H., Smeets, E., Bailis, R., Rooijakkers, M., Hooijkaas, N., Verweij, P. \& Faaij, A., 2014. Comparative analysis of key socio-economic and environmental impacts of smallholder and plantation based jatropha biofuel production systems in Tanzania. Biomass and Bioenergy, 61 (1), pp. 25-45.

37. Vanhove, W., Vanhoudt, N. \& Van Damme, P., 2016. Effect of shade tree planting and soil management on rehabilitation success of a 22-year-old degraded cocoa (Theobroma cacao L.) plantation. Agriculture, Ecosystems and Environment, 219 (1), pp. 14-25.

38. Xu, Q., Jiang, P. \& Xu, Z., 2008. Soil microbial functional diversity under intensively managed bamboo plantations in southern China. Journal of Soils and Sediments, 8 (3), pp. pp. 177-183.

39. Yi, Z.F., Cannon, C.H., Chen, J., Ye, C.X. \& Swetnam, R.D., 2014. Developing indicators of economic value and biodiversity loss for rubber plantations in Xishuangbanna, southwest China: A case study from Menglun township. Ecological Indicators, 36 (1), pp. 788-797.

40. Zhang, Y., Ni, J., Yang, J., Zhang, T. \& Xie, D., 2017. Citrus stand ages regulate the fraction alteration of soil organic carbon under a citrus/Stropharua rugodo-annulata intercropping system in the Three Gorges Reservoir area, China. Environmental Science and Pollution Research, 24 (22), pp. 18363-18371. 